\title{
Exosome-based immunotherapy: a promising approach for cancer treatment
}

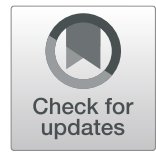

Zhijie $\mathrm{Xu}^{1 \dagger}$, Shuangshuang Zeng ${ }^{2 \dagger}$, Zhicheng Gong ${ }^{2,3}$ and Yuanliang Yan ${ }^{2 *}$ (D)

\begin{abstract}
In the era of the rapid development of cancer immunotherapy, there is a high level of interest in the application of cell-released small vesicles that stimulate the immune system. As cell-derived nanovesicles, exosomes show great promise in cancer immunotherapy because of their immunogenicity and molecular transfer function. The cargoes carried on exosomes have been recently identified with improved technological advances and play functional roles in the regulation of immune responses. In particular, exosomes derived from tumor cells and immune cells exhibit unique composition profiles that are directly involved in anticancer immunotherapy. More importantly, exosomes can deliver their cargoes to targeted cells and thus influence the phenotype and immune-regulation functions of targeted cells. Accumulating evidence over the last decade has further revealed that exosomes can participate in multiple cellular processes contributing to cancer development and therapeutic effects, showing the dual characteristics of promoting and suppressing cancer. The potential of exosomes in the field of cancer immunotherapy is huge, and exosomes may become the most effective cancer vaccines, as well as targeted antigen/drug carriers. Understanding how exosomes can be utilized in immune therapy is important for controlling cancer progression; additionally, exosomes have implications for diagnostics and the development of novel therapeutic strategies. This review discusses the role of exosomes in immunotherapy as carriers to stimulate an anti-cancer immune response and as predictive markers for immune activation; furthermore, it summarizes the mechanism and clinical application prospects of exosome-based immunotherapy in human cancer.
\end{abstract}

Keywords: Exosomes, Cancer immunotherapy, Cancer vaccines, Immune cells, Clinical implications

\section{Background}

Cancer is a major public health problem and the leading cause of death globally, and cancer incidence and mortality are rapidly growing worldwide. More than 18 million new cancer cases and 9 million cancer deaths are currently expected each year [1-3]. Common cancer treatments mainly include surgery, chemotherapy, radiotherapy and targeted therapy [4]. However, chemotherapy and/or radiotherapy, as the most important and effective therapeutic strategies for treating cancer, can also cause adverse reactions, drug resistance and long-term complications [5, 6]. Given the

\footnotetext{
* Correspondence: yanyuanliang@csu.edu.cn

${ }^{\dagger}$ Zhijie Xu and Shuangshuang Zeng contributed equally to this work.

${ }^{2}$ Department of Pharmacy, Xiangya Hospital, Central South University, 87 Xiangya Road, Changsha 410008, Hunan, China

Full list of author information is available at the end of the article
}

significant advances in drug screening technology, there is now emerging interest in oncology drug development that can overcome these problems by using a new cancer therapy strategy $[7,8]$. Cancer immunotherapy is type of a treatment that controls and clears tumors by regulating the immune system to reactivate the anti-cancer immune response and overcome the pathway leading to tumor escape $[9,10]$. Therapeutic approaches mainly include nonspecific immune stimulation, immune checkpoint blockades, adoptive cell transfer and vaccination strategies. Several immunotherapy drugs have been approved by the United States Food and Drug Administration (FDA) for clinical use, such as cytotoxic T-lymphocyte-associated protein 4 (CTLA-4) inhibitors, programmed cell death 1 (PD-1)

(C) The Author(s). 2020 Open Access This article is licensed under a Creative Commons Attribution 4.0 International License, which permits use, sharing, adaptation, distribution and reproduction in any medium or format, as long as you give appropriate credit to the original author(s) and the source, provide a link to the Creative Commons licence, and indicate if changes were made. The images or other third party material in this article are included in the article's Creative Commons licence, unless indicated otherwise in a credit line to the material. If material is not included in the article's Creative Commons licence and your intended use is not permitted by statutory regulation or exceeds the permitted use, you will need to obtain permission directly from the copyright holder. To view a copy of this licence, visit http://creativecommons.org/licenses/by/4.0/ The Creative Commons Public Domain Dedication waiver (http://creativecommons.org/publicdomain/zero/1.0/) applies to the data made available in this article, unless otherwise stated in a credit line to the data. 
inhibitors and programmed cell death 1 ligand 1 (PDL1) inhibitors [11-13]

Exosomes are single-membrane organelles with a diameter of approximately $30-100 \mathrm{~nm}$ that can be secreted by many types of cells, including cancer cells and immune cells [14]. The main molecular components of exosomes are cell-derived proteins, lipids, glycoconjugates and nucleic acids $[15,16]$. Exosomes have a variety of activities such as remodeling the extracellular matrix (ECM) as well as mediating the intercellular transmission of signals and molecules. With the study of multiple roles of exosomes in cancer progression, the dual characteristics of exosomes in promoting and suppressing cancer have been considered. As cell-derived nanovesicles, exosomes have potential uses in cancer immunotherapy because of their immunogenicity and molecular transfer functions [17].

In recent years, cancer immunotherapy has become a research hotspot because of its characteristics of strengthening the immune system, applicability to a variety of cancers, and an enduring response. It has shown strong anti-tumor activity in a variety of tumors, including melanoma, non-small cell lung cancer (NSCLC), and kidney cancer [18-20]. Exosomes released by cancer cells can alter different types of stromal cells to promote cancer cell growth and invasive behavior and to activate autocrine VEGF signaling in endothelial cells to promote tumor angiogenesis [21, 22]. Moreover, exosomes can also express molecules that mediate immunosuppression, such as PD-L1 and transforming growth factor- $\beta$ (TGF- $\beta$ ) [23]. Cancerderived exosomes can inhibit the proliferation and activation of CD8+ T cells and promote the expansion of regulatory $\mathrm{T}$ cells to play an immunosuppressive role [24]. Moreover, some surprising anti-cancer functions of exosomes have recently been revealed. Many studies have found that dendritic cell (DC)- and tumor-derived exosomes express a large number of major histocompatibility complex class I molecules (MHC I) and tumor markers such as heat shock proteins (HSP), which are involved in antigen presentation and stimulation of $\mathrm{T}$ cells and have been shown to trigger $\mathrm{CD} 8+\mathrm{T}$ cell-dependent anti-tumor responses in vitro and in vivo [25]. Therefore, as carriers to stimulate anti-cancer immune responses and deliver anti-cancer drugs, how exosomes could be utilized in immune therapy is important in regards to cancer progression and they have implications for diagnostics and the development of novel therapeutic strategies. In this review, we focused on the function and mechanism of exosome-based immunotherapy in human cancer, its significant therapeutic effect on cancer progression and the possibility of developing immunotherapeutic vaccines.

\section{The regulatory role of exosome-based immune responses}

The immune response refers to the body's defensive response to harmful substances that are foreign or selfmutated. The immune response can be divided into the innate immune response and the adaptive immune response. Different types of immune cells are involved in the above nonspecific and specific immune responses. Phagocytes (including monocytes, macrophages and DCs) and natural killer (NK) cells are involved in innate immunity and constitute the first line of defense against pathogens; they also synergistically participate in the adaptive immune response. The adaptive acquired immune response utilizes $\mathrm{T}$ and $\mathrm{B}$ lymphocytes and their immunoglobulins and cytokines to produce a specific and heterogeneous response to invading microorganisms [26-28]. Currently, efforts are being made in the field of immunotherapy to find new low-toxicity inhibitors and better biosafety delivery vectors. Therefore, exosomebased therapy is a potential new approach to cancer immunotherapy because exosomes can be used as carriers to initiate anti-cancer immune responses and as a tool to deliver anti-cancer drugs [29] (Fig. 1). In the following chapter, the immune stimulatory and suppressive effects of exosomes secreted from different cells will be explained in detail (Fig. 2).

\section{Tumor-released exosomes}

Tumor-released exosomes have been widely studied in various types of cancer, such as renal cancer, hematological cancer, breast cancer and melanoma. Tumor-associated exosomes (TAEs) have essential roles in DCs participating in anti-cancer immune responses. Cooperating with DCs, exosomes from a rat pancreatic adenocarcinoma can activate tumor-antigen-specific cytotoxic $\mathrm{T}$ cell (CTL) responses and affect leukocyte proliferation through reduced CD44v6 upregulation and lck, ZAP70 and ERK1,2 phosphorylation [30]. A study of pancreatic cancer later found that miRNA-depleted exosome proteins may act as agonists for specifically activating DC/cytokine-induced killer cells (DC/CIK) [31]. In research on NSCLC, exosomes from Rab27aoverexpressing tumor cells have been shown to promote the maturation of DCs by upregulating major histocompatibility complex class I molecules (MHC II) and the costimulatory molecules CD80 and CD86, significantly promoting the proliferation and response of $\mathrm{CD} 4+\mathrm{T}$ cells in vitro and in vivo [32]. More importantly, TAEs decreased the expression of PD-L1 on DCs, leading to the downregulation of Tregs in vitro [33]. In addition to upregulating MHC II and costimulatory molecules, TGF- $\beta 1$-silenced leukemia cell-derived exosomes promote DC function by inducing the secretion of interleukin (IL)-12p70 and tumor necrosis factor (TNF)- $\alpha$ [34]. 


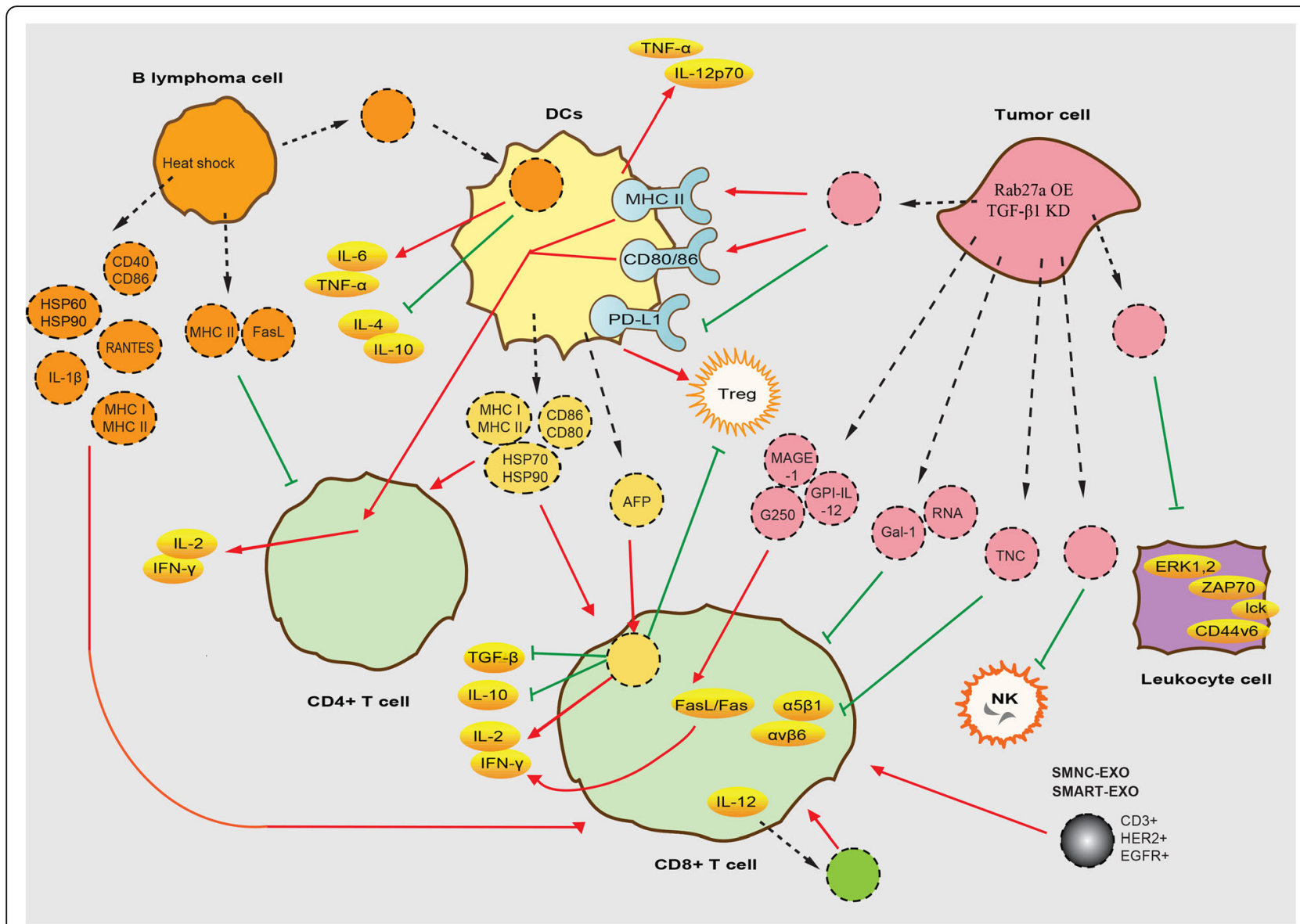

Fig. 1 Regulatory mechanisms of exosomes released by different cells on immune cells. Exosomes' entry and exit into cells is indicated by black dotted lines. Exosomes are represented with the same color as the host cell. OE: overexpression. KD: knock-down

The purpose of cancer immunotherapy is to promote the activity of intracellular CTLs, assist in the initiation of tumor-specific CTLs in lymphoid organs, and establish effective and lasting anti-cancer immunity; thus, CD8+ $\mathrm{T}$ cells are the key to controlling cancer [35]. In immunotherapy, by ensuring the transmission of signals from $\mathrm{CD} 4+\mathrm{T}$ cells to $\mathrm{CD} 8+\mathrm{T}$ cells and regulating the metabolic activities of $\mathrm{T}$ cells, the CTL response can be optimized, which may enhance anti-cancer immunity [36]. In renal cancer, exosomes derived from glycolipidanchored-IL-12 (GPI-IL-12) gene-modified tumor cells express the tumor-associated antigen MAGE-1 and tumor rejection antigens G250 and GPI-IL-12, which significantly promote $\mathrm{T}$ cell proliferation and increase interferon (IFN) $-\gamma$ in turn, and efficiently trigger a stronger activity of CTLs through the FasL/Fas signaling pathway [37, 38]. Breast cancer exosomes inhibit both $\mathrm{CD} 8+$ and $\mathrm{CD} 4+\mathrm{T}$ cell proliferation by initiating cell apoptosis and suppressing NK cell cytotoxicity and, hence, may inhibit the anticancer immune response [39]. In head and neck cancer, TAEs have been shown to induce a suppressor phenotype in $\mathrm{CD} 8+\mathrm{T}$ cells in the synergistic action of exosomal proteins such as galectin1 (Gal-1) and RNA [40]. Exosomes derived from B16F0 melanoma cells suppress cytotoxic immunity by altering the transcriptome of CTLs so that their mitochondrial respiration is not dependent on substrates or hypoxia [41]. Subsequent studies confirmed that in leukemia cell derived exosomes, silencing exosomal TGF- $\beta 1$, which reduces the level of immunogenicity, can promote CD4+ $\mathrm{T}$ cell proliferation and Th1 cytokine (IFN- $\gamma$ and IL-2) secretion, effectively stimulating the CTL response and the cytotoxicity of NK cells [34]. Brain tumor-initiating cells secrete exosomes for the output of ECM protein tenascin- $\mathrm{C}$, which can inhibit the proliferation of $\mathrm{T}$ cells by interactions of $\alpha 5 \beta 1$ and $\alpha v \beta 6$ integrins associated with the reduction of mTOR signal transduction [42]. In addition, exosomes secreted by mesenchymal stem cells have been investigated to promote the proliferation and immunosuppressive capacity of Tregs by upregulating IL-10 and TGF- $\beta 1$ in peripheral blood mononuclear cells (PBMCs), and they may play an immunomodulatory role in PBMCs from asthmatic patients through the antigen presenting cell (APC)-dependent pathway [43]. 


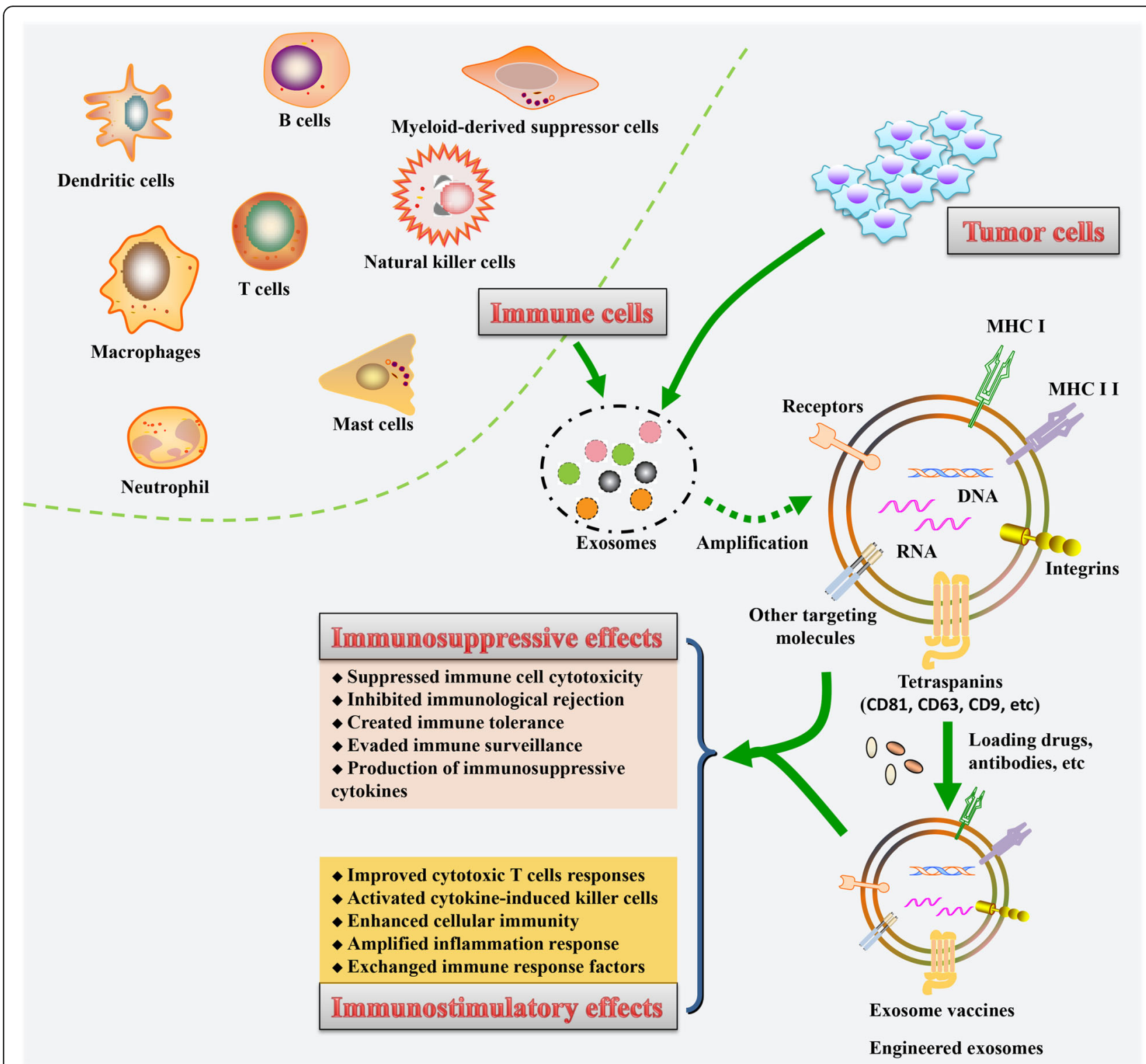

Fig. 2 The immune stimulatory and suppressive effects of cells-derived exosomes. This schematic displays the underlying mechanisms and functions of exosomes released from tumor cells and immune cells in the regulation of immune responses in tumor-bearing hosts

There is ample evidence that TAEs bearing NK ligands are usually able to evade immune surveillance and responses [44, 45]. As reported in the literature, NK cells in host immunity against cancers are predominantly mediated by active receptors, such as NKG2D, NKp44, etc [44]. However, TAEs from tumor cell supernatants and sera of leukemia patients decrease the cytotoxic activity of host NK cells by shedding NKG2D, thereby subverting the host immune system and contributing to the tumor-promoting microenvironment [46, 47]. Similarly, exosomes produced by human solid cancers, including prostate cancer [48] and ovarian cancer [49], can selectively downregulate NKG2D levels on NK cells by expressing NKG2D ligands, ultimately leading to impaired NK cell-mediated cytotoxic function and promotion of tumor immune evasion. In addition, it was demonstrated that TGF- $\beta 1$, serving as a major immunosuppressive cytokine, restrains the cytolytic effect of NK cells through activation of the Smad2/3 signaling pathway [50]. A subsequent study by Zhao et al. showed that TAEs can induce Smad2/3 phosphorylation in NK cells and attenuate NK cell cytotoxicity against pancreatic cancer stem cells [51]. Unexpectedly, some contrary findings revealed that exosomes originating from HSO70/BAG4-positive tumor sublines have been shown to stimulate the killing effect of NK cells against HSP70- 
positive tumors [52]. Additionally, in response to genotoxic stress signals, some malignancies release BAG6+ or HSP70+ exosomes and promote NK cell-mediated anti-tumor responses by engaging the active receptors CD69, NKG2D, NKp44 and NKp46 [53-55]. Thus, depending on their cellular origin and environmental conditions, TAEs might display different functional roles in the NK cell-dependent immune response to tumors, which needs more clarification in the future.

\section{Dendritic cell-derived exosomes}

DCs play an important role in tumor immunity due to their ability to absorb and express tumor-associated antigens, and they are important targets in cancer immunotherapy. However, their anti-tumor effect has been unsatisfactory due to the poor immunogenicity of tumor antigens, low uptake efficiency of antigens, and the activation of regulatory $\mathrm{T}$ cells [56]. At present, studies have reported that exosomes can be used as the ideal antigen for DC vaccines [57]; thus, it is necessary to explore the mechanism of anti-tumor immunity induced by exosome-based DC vaccines and then confirm whether exosomes can be used as tumor antigens for DC vaccine-based immunotherapy.

As the most effective antigen-presenting cell, DCs also secrete a large number of exosomes to induce effective anticancer effects. DC-derived exosomes (DEX), containing MHC I, MHC II, CD86 and HSP70-90 chaperones, are able to trigger $\mathrm{CD} 4+$ and $\mathrm{CD} 8+\mathrm{T}$ cell activation $[58,59]$. Under the costimulation of secreted IL-2 and exosomal CD80, the expression of exosomal peptide MHC I is passed to $\mathrm{CD} 8+\mathrm{T}$ cells, thereby stimulating the proliferation of CD8 $+\mathrm{T}$ cells and inducing more effective anti-tumor immunity in vivo [60]. Additional studies have verified that DEX activates $\mathrm{CD} 8+$ and CD4+ $\mathrm{T}$ cells and induces an anti-tumor immune response by exosomal CD80 and endogenous IL-2 in vivo [61, 62]. In addition, exosomes derived from $\alpha$-fetoprotein (AFP)-expressing DCs stimulated mice with hepatocellular carcinoma to produce more IFN- $\gamma$-expressing CD8+ T cells, with increased IFN- $\gamma$ and IL-2 and reduced CD25+Foxp3+Tregs, IL-10 and TGF- $\beta$ [63]. Although it is widely believed that DEX containing MHC promotes $\mathrm{T}$ cell responses [64], it is controversial that some studies have found that the $\mathrm{T}$ cell response can be independent of the MHC contained in DEX if whole antigens are present [65].

\section{B lymphoma cell-derived exosomes}

It has been reported that exosome-based DC vaccines can stimulate clonal expansion of $\mathrm{T}$ cells by pulses of exosomes derived from diffuse large B cell lymphoma cells [66]. In contrast, exosomes from B cell lymphoma cells have been found to induce apoptosis in CD4+ T cells via MHC II and FasL [67]. Exosomes secreted by B lymphoma cells subjected to heat shock contained more HSP60 and HSP90 and exhibited an increased levels of immunogenicity molecules, such as MHC I, MHC II, CD40, CD86, RANTES and IL-1 $\beta$, thus effectively activating CD8+ T cells to produce an antitumor effect [68]. Regarding exosomes derived from diffuse large B cell lymphoma cells, DCs can stimulate clonal expansion of $\mathrm{T}$ cells by pulsing with these exosomes, increasing the secretion of IL- 6 and TNF- $\alpha$ and reducing the production of immunosuppressive cytokines IL-4 and IL-10 [66].

\section{T lymphocyte cell-derived exosomes}

Immunotherapy using genetically engineered $\mathrm{T}$ cells to express chimeric antigen receptor (CAR) is rapidly becoming a promising new therapy $[69,70]$. T cells can be mainly divided into two types according to phenotype, with corresponding receptors on their surfaces and antigen specificity, including CD4+ helper $\mathrm{T}$ cells and CD8+ CLTs. Because of their unique functions and different surface antigens, CD4+ helper $\mathrm{T}$ cells can be further divided into several groups, including Th17 cells, regulatory $\mathrm{T}$ cells (Tregs), and follicular helper $\mathrm{T}$ cells (Tfhs), etc [71, 72]. CD8+ CTLs that bind directly to antigens via $\mathrm{MHC}$ I enhance cellular immunity against intracellular pathogens and malignant cells. Apart from the direct killing effects on tumor cells, activated CD8+ $\mathrm{T}$ cells can also eliminate tumor cells by releasing exosomes [73]. In an in vivo study with a mouse model of melanoma, intratumoral administration of activated CD8+ $\mathrm{T}$ cell-derived exosomes caused interruption of fibroblastic stroma-mediated tumor invasion and metastasis [74]. Although, most CTLs are low-affinity, highaffinity CTLs are considered more essential to the immune response due to their highly robust function and increased sensitivity to detection. A recent study has shown that in the presence of IL-12, high-affinity CTLs secrete exosomes that activate low-affinity CTLs that are important in the immunotherapy of cancer [75]. The exosomes from IL-12-stimulated CTLs also activate bystander $\mathrm{CD} 8+\mathrm{T}$ cells to produce IFN- $\gamma$ and granzyme B (GZB), ultimately destroying infected cells [76]. Other findings showed that CD63-expressed exosomes from $\mathrm{T}$ cells are known to carry specific miRNAs that regulate the immune response and immune system development, and play an important role in promoting intercellular APC-T cell communications [77]. CD63+ exosomes exert the same anti-infective properties as $\mathrm{CD} 8+\mathrm{T}$ cells [78]. Thus, activated CD8+ T cell-derived exosomes can link cytotoxic $\mathrm{T}$ cells to targeted cells, and enhance CTL-based immunotherapy. However, FasL-expressed exosomes from activated CD8+ $\mathrm{T}$ cells unexpectedly promoted the metastasis of Fas-resistant tumor cells 
through the activation of ERK/NFKB signaling pathways [79]. Xie et al. further demonstrated the suppressive effect of $\mathrm{T}$ cell-derived exosomes on DC-mediated CTL responses and antitumor immunity through the downregulation of MHC I and FasL signaling [80]. In addition, exosomes from exhausted CD8+ T cells can be taken up by functional $\mathrm{CD} 8+\mathrm{T}$ cells, thus impairing their activity and secretion of cytotoxic factors [81]. Thus, these paradoxical discoveries may allow us to better understand the detailed functions of CD8 $+\mathrm{T}$ cell-released exosomes under different circumstances and shed light on systematic studies of dysfunctional anticancer immunity.

CD4+ helper $\mathrm{T}$ cell surface markers are mainly CD4, which is activated or adjusted or assists in immune responses when combined with MHC II on the surface of APCs. The exosomes isolated from CD4+ helper $\mathrm{T}$ cells contain both exosome-associated proteins (LAMP-1, TCR and LFA-1) and CD4 T cell markers (CD4, TCR, LFA-1, $\mathrm{CD} 25$ and FasL) and participate in CTL responses and antitumor immunity [82]. Moreover, altered expression of bioactive messengers on CD4+ $\mathrm{T}$ cell-derived exosomes has been demonstrated to be the underlying pathogenic mechanism for some inflammatory diseases [83]. Along similar lines, these exosomes can interact with target cells via CD4-MHC interactions, and ultimately eliminate immunodeficient cells [84]. In addition, activated CD4+ helper $\mathrm{T}$ cell-released exosomes can also serve as a potent inducer for the activation of phagocytes and B cells, contributing to amplifying the inflammatory response $[85,86]$.

Recent studies have shown that Treg cells are responsible for negatively regulating the body's immune response and maintaining immunological tolerance [87], and CD4+CD25+ Treg cells are the most active cells in the current research. Recent findings suggest that Treg cells also control immune responses via the production of secreted exosomes. Treg-exosomes are reported to contain unique molecular cargoes of bioactive messengers (specific miRNAs and iNOS). Once delivered into target cells, these cargoes can block cell cycle progression, induce apoptosis [88, 89], and suppress CTL-mediated anti-cancer immunity [90]. A recent report conducted by Chen et al. showed that exosomes secreted by Treg cells, especially donor-type Tregs, are known to inhibit immunological rejection and create immune tolerance by impairing selfreactive CD8+ $\mathrm{T}$ cells during organ transplantation [91]. In particular, the expression of CD73 on Treg cell-derived exosomes is essential for their suppressive function [92]. These inhibitory effects on the immune system can be evidently reversed after treatment with GW4869, an exosome inhibitor [93].

\section{Natural killer cell-derived exosomes}

As an important component of the innate immune system, NK cells contribute to immunosurveillance and function as the body's first-line of defense against several human disorders, including pathogen infections and cancers. NK cells can directly recognize and effectively kill oncogenic transformed cells that are normally devoid of class I MHC antigen expression, participating in anticancer immunity [94]. Recently, NK cells have also been proven to be involved in the control of the immune response using other methods independent of the cell activation status, one of which is via exosomes [95]. More importantly, exosomes derived from NK cells also harbor prototype NK markers (e.g., CD56) and killer proteins (e.g., FasL and perforin) [96]. Additionally, NKexosomes can exert their cytolytic activity by directly diffusing into tumor tissues, and subsequently overcome the homing deficiency of NK cells to tumor sites [97]. Several studies were recently performed to investigate the profiles of NK cell-derived exosomes in cancer patients. In addition to exosome-specific markers (e.g., tsg101, CD81, CD63 and CD9), NK cell markers (e.g., NKG2D, CD94, perforin, granzymes and CD40L) were also expressed in NK-derived exosomes, which are both involved in cytotoxicity and immune response [98, 99]. These exosomes can induce target cell death by multiple killing mechanisms. Accordingly, after treatment with NK exosomes, both CHLA255 neuroblastoma cells and SupB15 leukemia cells showed significantly activated caspase-independent and caspase-dependent cell death pathways [100]. Furthermore, NK cell-derived exosomes strengthened the anti-cancer activity of CD56+ NK cells [98]. In addition, targeted delivery of tumor suppressors by NK-exosomes resulted in effective inhibition of tumorigenic potential and immune escape mechanisms [101]. The immunotherapeutic potential and tumortargeting ability of NK-exosomes can be further improved after IL-15 priming of NK cells [102]. NK cells can be obtained from both autologous and allogeneic sources [103], providing more clinical applications for NK-exosomes. Taken together, these findings indicate that NK cell-derived exosomes can potentially be exploited in support of cancer immunotherapy. However, one question limiting their clinical applications remains to be answered: how can functional NK-exosomes be isolated on a large scale? To address this issue, Jong et al. recently conducted a polymer precipitation method to isolate a large quantity of NK-exosomes [104], which may lay the foundation for their future applications in the clinic.

\section{Myeloid-derived suppressor cell-derived exosomes} Myeloid-derived suppressor cells (MDSCs), a heterogeneous group of immature myeloid cells, have a remarkable capacity to suppress $\mathrm{T} / \mathrm{NK}$ cell cytotoxicity and serve as a major obstacle in cancer immunotherapy $[105,106]$. The therapeutic efficacy of inhibiting 
MDSCs by pharmacological agents in cancers has been well reviewed [107]. Recently, several reports have preliminarily described the immunosuppressive roles of MDSC-exosomes within the microenvironment in cancers and autoimmune diseases [108-110]. The cargoes present in MDSC-exosomes have been proven to be consistent with their involvement in MDSCmediated immune suppression [111]. Notably, upon doxorubicin treatment, the improved MDSC-derived miR-126a+ exosomes could promote metastasis and therapeutic resistance in breast tumor-bearing mice [112]. Elimination of MDSC-exosomes fosters the anticancer immunotherapeutic response [113]. Nonetheless, additional detailed research should be conducted to evaluate the interaction between MDSC-exosomes and other tumor-infiltrating immune cells, and their relevance in cancer immunotherapy. A better understanding of the biological function of MDSC-released exosomes will be important for their future therapeutic applications in cancer patients.

\section{Tumor-associated macrophage-derived exosomes}

In the tumor microenvironment, macrophages have the ability to suppress $\mathrm{T}$ cell function, thereby facilitating tumor immune escape [114]. However, tumorassociated macrophages (TAMs) often exert two opposing phenotypes: anti-tumorigenic M1 subtype and pro-tumorigenic M2 subtype [115]. Accumulating evidence indicates that TAMs also secrete exosomes to modulate multiple aspects of cancer biology and the immune response [116, 117]. Exosomes released from TAMs induce a Treg/Th17 imbalance by transferring miRNAs into CD4+ T cells, thus directly generating an immune-suppressive microenvironment and promoting ovarian cancer progression [118]. Recently, several studies have shown that TAM-exosomes with immunosuppressive activity are predominantly released from M2 subtype macrophages, and promote cancer progression and therapeutic resistance [119, 120]. Accordingly, M2-derived exosomes determine TAM-mediated promigratory activity by transferring functional apolipoprotein $\mathrm{E}$ into recipient gastric cancer cells [121]. M2 macrophagederived exosomes also accelerate cancer cell migration, invasion and chemotherapy resistance by transferring oncogenic miRNAs [122, 123]. However, comprehensive molecular profiling and functional analysis have revealed that TAM-derived exosomes predominantly present Th1/ M1 polarization signatures, and their cargoes enhance pro-inflammatory signaling and the immune response [124]. Furthermore, in a model of tumor-bearing mice, intravenous injection of M1 macrophage-derived exosomes can repolarize M2 to M1 macrophages in the microenvironment and significantly potentiate the anticancer efficacy of PD-L1 inhibitors [125]. In addition, these exosomes can act as transmitters to exchange components among other immune cells and to enhance the immune response. For example, Xu's group demonstrated that these exosomes function as potential vehicles to convey phagocytosed antigens to DCs and finally strengthen T-cell responses [126]. Even though the immuneregulatory roles of TAM-exosomes require additional studies to clarify, these findings suggest that TAM-derived exosomes have the potential to increase anti-tumor immunity.

\section{Mast cell-derived exosomes}

Mast cells (MCs) can secrete exosomes that display biological functions in RNA and protein transfer, intercellular communication and immunoregulation [127, 128]. It was pointed that $\mathrm{MC}$-exosomes have been reported to destroy intestinal barrier function, which is attributed to exosome-carried miRNAs transferred to targeted cells [129]. Recent studies found that MC-derived exosomes can be taken up by lung cancer cells, and subsequently increase cancer cell proliferation by transferring KIT protein [130]. Morphological analysis about the effects of these exosomes on lung epithelial tumor cells revealed an epithelial to mesenchymal transition-like phenotype in exosome-recipient A549 cells. Transcript analysis further indicated that the EMT-associated phosphorylation cascades were obviously upregulated by MC-exosome treatment [131]. In addition, MC-derived exosomes can affect the biological functions of DCs, T cells and B cells. For example, CD63+ and OX40L+ exosomes from MCs promote the proliferation and differentiation of CD4+ Th2 cells via the OX40L-OX40 interaction [132]. MCexosomes also induce immature DCs to upregulate MHC II, CD40, CD80, and CD86 molecules and to confer antigen-presenting capacity to $\mathrm{T}$ cells, thereby leading to the initiation of antigen-specific immune responses [133]. However, currently, the effect of MCreleased exosomes on the anti-cancer immunity is still under investigation and might be a highly attractive topic in the future.

\section{Neutrophil-derived exosomes}

Proteomic and RNA microarray analyses indicate that neutrophil-derived exosomes contain proteins, mRNA and miRNAs, which are associated with inflammatory reactions, immune response and cell communication [134-136]. Functional studies further discover that neutrophil-derived exosomes can affect the activity of other immune cells, such as macrophages, by transferring several proinflammatory factors [137]. These exosomes have been reported to bind and degrade ECM via integrin Mac-1 and neutrophil elastase (NE), consequently leading to inflammatory disease progression [138]. Conversely, $\mathrm{Li}$ et al. recently found that these 
exosomes significantly suppress the proliferation and migration of endothelial cells, thereby impairing pathological angiogenesis in immune disorders [139]. In addition, Vargas et al. preliminarily confirmed the tumor susceptibility gene 101 in neutrophil-derived exosomes [134]. However, to the best of our knowledge, no relevant studies have been conducted to explain the underlying molecular mechanisms of neutrophilderived exosomes in the regulation of antitumor immune responses.

\section{Exosome-based immunotherapy in animal models}

The potential of exosomes in the field of cancer immunotherapy is huge, and exosomes may become the most effective cancer vaccines as well as targeted antigen/drug carriers. Since exosomes can induce tumorspecific immunity, they have attracted wide attention as potential cancer vaccines, and animal and clinical trials have been conducted to verify their efficacy (Table 1). Recent studies have begun to expand our understanding of the role of TAEs in DC-mediated anti-cancer immune responses, and revealed the potential of TAEs as a new approach to cancer vaccines [140].

TAEs can effectively act on DCs, thus inducing a stronger immune response and making up for the deficiency of DC immunotherapy [141]. After entering the systemic circulation, exosomes generated from BALB/c mice can transmit signals to the immune system, which can then induce the maturation of DCs and the activation of T cells [142]. In further research on tumor-bearing mice vaccinated with TAE-loaded DC, the TAEs were effectively ingested by DCs and subsequently upregulated the expression of CD11c, MHC II, and IL-12 [143].
Plasmacytoma cells release exosomes containing tumor antigens (P1A and intracisternal A particle protein) and HSP70 protein. They were used as a vaccine, and the vaccinated mice could produce specific CTLs, inducing tumor-specific immunity [144]. Exosomes derived from a CIITA (Class II transactivator) gene modified B16F1 murine melanoma cell line for use as a vaccine (CIITA-Exo) can express MHC II and tumor antigen TRP2. CIITA-Exo were injected into mice and they were confirmed to induce a Th1polarization immune response, including upregulation of Th1 IgG2a antibodies, IFN- $\gamma$ cytokines and TRP2 specific CD8+ T cells [145]. Exosomes derived from malignant mesothelioma cells can be used as an antigen source for DC-based immunotherapy, and tumorbearing mice that received tumor exosome-loaded DC immunotherapy had higher survival rates [146]. However, since tumor-derived exosomes can not only stimulate the anti-tumor immune response but also promote immunosuppression and interfere with antitumor immunotherapy, it is necessary to understand the immune-stimulating mechanism of exosomes so that they can be used as adjuvants and antigenic components of anti-tumor vaccines [147].

In addition, effective dual exosome vaccines against melanoma (B16) and Lewis lung carcinoma (LLC) have also been developed to generate DEX carrying tumor antigens from B16 and LLC cells, which can inhibit the development of both tumors in mice after vaccination [148]. DEX loaded with the iNKT-cell ligand $\alpha$-galactosylceramide $(\alpha G C)$ activates CD4+ T cells, OVA-specific CD8+ T and $B$ lymphocytes, which then improves the survival rate and survival time in a B16 melanoma mouse model [149].

Table 1 The potential of exosomes as a new approach to cancer vaccines in animal models

\begin{tabular}{|c|c|c|c|c|c|}
\hline Animal Models & Cancer & External stimulus & Exosome source & Clinical significance & Reference \\
\hline BALB/c mice & None & $\begin{array}{l}\text { Exposure to magnetic iron oxide } \\
\text { nanoparticles }\end{array}$ & From alveolar region & $\begin{array}{l}\text { Induce the maturation } \\
\text { of DCs and activation } \\
\text { of T cells }\end{array}$ & [142] \\
\hline WEHI3B-bearing mice & Leukemia & Vaccination with TAE-loaded DC & TAE & $\begin{array}{l}\text { Upregulate CD11C, } \\
\text { MHC II and IL-12 in DC }\end{array}$ & [143] \\
\hline $\begin{array}{l}\text { Mouse plasmacytoma } \\
\text { model }\end{array}$ & Plasmacytoma & $\begin{array}{l}\text { Vaccination with a single dose } \\
\text { (5 microg) of exosome protein }\end{array}$ & From plasmacytoma cells & $\begin{array}{l}\text { Produce specific CTLs, } \\
\text { induce tumor-specific } \\
\text { immunity }\end{array}$ & [144] \\
\hline C57BL/6 mice & Melanoma & Vaccination with CIITA-Exo & CIITA gene modified TAE & $\begin{array}{l}\text { Trigger Th-1 type } \\
\text { immune responses }\end{array}$ & [145] \\
\hline BALB/c mice & $\begin{array}{l}\text { Malignant } \\
\text { mesothelioma }\end{array}$ & Vaccination with TAE-loaded DC & TAE & $\begin{array}{l}\text { Increase median and } \\
\text { overall survival of mice }\end{array}$ & [146] \\
\hline Tumor-bearing mice & $\begin{array}{l}\text { Melanoma and } \\
\text { Lewis lung } \\
\text { carcinoma }\end{array}$ & $\begin{array}{l}\text { Vaccination with DEX bearing } \\
\text { antigens from two types of tumor }\end{array}$ & DEX & $\begin{array}{l}\text { Prevents both tumors } \\
\text { growth in mice }\end{array}$ & [148] \\
\hline B16-bearing mice & Melanoma & $\begin{array}{l}\text { Vaccination with DEXs loaded } \\
\text { with the iNKT-cell ligand aGC }\end{array}$ & DEX & $\begin{array}{l}\text { Activate CD4+ and } \\
C D 8+T \text { cells, increase the } \\
\text { survival of mice }\end{array}$ & [149] \\
\hline
\end{tabular}




\section{Exosomes: effective markers for the adaptive immune activation of immunotherapy}

Immunotherapy has become an important treatment choice for cancer patients. Currently, these existing biomarkers of immunotherapy are characterized by a low efficiency of responder stratification and high risk due to the need for invasive operations, so it is urgent to identify new biomarkers. For example, TAEs and CD3+ T cell-derived exosomes of head and neck squamous cell carcinoma patients who received a combination of cetuximab, ipilimumab, and radiotherapy, can replace immune cells to monitor the response of the patient to tumor therapy [150]. In addition for initiating immune responses and delivering drugs, exosomes have been found to be predictive markers for adaptive immune activation of immunotherapy $[151,152]$.

The activation of $\mathrm{T}$ and $\mathrm{B}$ cells in the adaptive immune response occurs in lymphoid tissues and is assessed primarily by evaluating the titer of serum antibodies and the responses of peripheral blood $\mathrm{T}$ lymphocytes. Exosomal PD-L1 is a potential early marker of adaptive immune activation after immunotherapy with PD-1 blocking antibodies in melanoma patients and predicts a clinical response [23]. Blocking the PD-1 pathway increased the production of IFN- $\gamma$ by PD-1+CD8+ T cells, which in turn induced the expression of PD-L1 in various cells in the tumor microenvironment. In the early stages of immunotherapy in melanoma patients, there was a significantly higher increase in exosomal PD-L1 among responders, while there were no significant differences in other types of PD-L1, suggesting that exosomal PD-L1 is a marker of adaptive immune activation.

Studies have shown that activated lymphocytes release a large number of exosomes containing microRNAs, such as miR-150, and the microRNA characteristics of CD4+ T cell-derived exosomes are significantly different from intracellular microRNA characteristics in the same cells. After vaccination with adjuvant-OVA, the serum miR-150 level in normal mice increased significantly, to a level similar to that of immune mice that were depleted of mature CD4+ T lymphocytes. This suggests that when the immune system is activated after vaccination, the lymphocytes involved in the response will release a large number of easily detectable exosomes into the blood; thus, there are also easily measured levels of lymphocyte-derived exosomal microRNAs [153]. Similarly, plasma exosomal microRNAs from patients have been identified as potential biomarkers for immunotherapy of NSCLC. A controlled study of patients with advanced EGFR/ALK wild-type NSCLC who received PD-1/PD-L1 inhibitors showed that compared with normal controls, NSCLC patients had more than 150 differentially expressed exosomal microRNAs. Among them, it was found that low levels of exosome-derived hsa-
miR-320d, hsa-miR-320c, and hsa-miR-320b may indicate the better efficacy of PD-1/PD-L1 immunotherapy in advanced NSCLCs. In addition, when hsa-miR-125b$5 \mathrm{p}$, a T-cell suppressor in exosomes, is downregulated during immunotherapy, NSCLC patients may gain enhanced T-cell function and respond well [154].

\section{Exosomes: underlying targets for the regulation of cancer immunotherapy}

The molecular mechanisms involved in targeting exosomes as cancer vaccines may provide important insights into immune recognition and therapeutic interventions [155]. More importantly, exosomes contain large amounts of tumor antigens such as MHC I and can be used as cell-free vaccines in cancer immunotherapy [156]. In the presence of APC, DCderived exosomes have been reported to load multiple peptide antigens (e.g., MHC I, MHC II), and thereby stimulating both CD4+ helper T cells and CD8+ CLTs to participate in the anti-tumor response [157]. In a mouse model of pancreatic cancer, subcutaneous injection of TAE-DC vaccines significantly recovered the activated $\mathrm{T}$ cells in the tumor environment and improved the therapeutic effect [158]. Furthermore, vaccination within TAE-exosome loaded $\mathrm{T}$ cells (exosome-T) has the ability to counteract CD4+CD25+ Treg cell-mediated immunosuppression and to trigger longterm CTL memory, providing attractive strategies for inducing immune responses against human cancers $[60,159]$. Similarly, the HER2-specific exosome-T vaccine was recently developed to efficaciously strengthen the patient's immune system against HER2-positive breast cancer [160]. However, exosome-based strategies also have immunosuppressive effects and may alleviate the immune response against cancer by inducing apoptosis of activated CD8+ T cells to interfere with immunotherapy [161]. Even so, the use of exosome-vaccination for immunotherapy can still be considered by adjusting the delivery route, dose, and modification of targeted exosomes.

To improve the targeting of exosomes and overcome the limitations of autologous use, many studies have genetically engineered exosomes to express specific antigen molecules or target cancer cells to enhance anti-cancer immunogenicity [162]. For example, a new synthetic polyvalent antibody redirected exosome (SMART-EXO) was produced by using the transmembrane domain of human platelet-derived growth factor receptor to display two different types of monoclonal antibodies on the surface of an exosome. By targeting the $\mathrm{CD} 3$ receptor on the surface of T cells, SMART-EXOs with the breast cancer-related HER2 receptor and EGFR receptor can activate CTLs, which then exhibit highly potent and specific anti-tumor activity both in vitro and in vivo [163, 164]. In addition, antigens can also be artificially transfected into exosomes. For example, HEK293 cell-released exosomes can be transfected with EBV protein gp350 and thus activate T 
cells by expressing gp350 to target CD19 on B cells, providing a novel strategy for the immunotherapy of $\mathrm{B}$ lymphocytic leukemia [165]. To date, emerging studies have provided novel insights into the development of exosome-based drug delivery systems for cancer treatment. It should also be noted that because of their natural properties, exosomes are less toxic and immunogenic, and can serve as attractive carriers of cytotoxic agents, such as paclitaxel, docetaxel and doxorubicin, with better stability and higher specificity for targeted tumor cells [166-168]. Therapeutic agent-carried exosomes have the ability to exert dual inhibition of targeted tumor growth [169]. Currently, a dual-functional exosome-based superparamagnetic nanoparticle cluster (SMNC-EXO) has been developed using multiple superparamagnetic nanoparticles anchored to each exosome to form a cluster. Then in the presence of external magnetic fields, SMNCEXOs have a powerful capability to deliver therapeutic drugs to targeted cancer cells [170]. Thus, it will be interesting to explore the possibility of exosome-associated technologies as potential therapeutic options for anticancer immunotherapy.

\section{Clinical implications}

Based on extensive research into the role of exosomes in cancer immunotherapy and their relevance as diagnostic and therapeutic targets, a large number of clinical trials have been conducted with exosomes. Targeting TAE dysregulation pathways, such as the heparinase/syndecan-1 axis, is a new approach to cancer treatment in the context of the role of TAEs in promoting cancer cell survival and growth $[171,172]$. Exosomes are also used as therapeutic markers in immunotherapy. In patients with malignant glioma receiving anti-survivin immunotherapy, the decreased release of $\mathrm{CD} 9+/ \mathrm{GFAP}+/ \mathrm{SVN}+$ and $\mathrm{CD} 9+/ \mathrm{SVN}+$ exosomes may be related to the prolonged progression-free survival of patients [173]. Furthermore, new evidence suggests that tumor cell-derived exosome DNA (ExoDNA) can also activate immune cells by STING/cGAS, and therefore, ExoDNA can both regulate tumor immunity and act as a key regulator of checkpoint immunotherapy [174].

The first exosome phase I trial conducted with vaccination of metastatic melanoma patients with autologous DEX verified the safety of exosome administration. However, since no specific CD4+ or CD8+ $\mathrm{T}$ cell responses were detected in the peripheral blood, it is still necessary to investigate the mechanism of vaccine antigen diffusion observed in this phase I trial [175]. In addition, the use of DEX in clinical trials of patients with NSCLC has been shown to mediate MAGE specific T cell responses and increase NK lysis activity [176]. DEX derived from blood cells in cancer patients has been shown to be safe and feasible for immunotherapy and has been successfully used in some small clinical trials, such as the phase II clinical trial in France of a DEX with a T-cell-dependent antitumor effect [177]. Even in the brain, which was previously thought to be able to block the entry of tumor-specific immune cells, DEX has been shown to be effective against glioma in mice, suggesting that DEX immunotherapy may be a new treatment for brain tumors [178]. DEX immunotherapy leads to a more precise and accurate immune response against tumor cells than other noncell-based therapies. Compared with other cell-based therapies, DEX immunotherapy has higher bioavailability and biostability, with higher yields and lower costs [179].

In ongoing clinical trials, exosomes are considered immunotherapeutic vaccines, markers of cancer diagnosis, prognosis, recurrence and metastasis, or drug delivery carriers for cancer treatment (Table 2). Exosomes as immunotherapeutic vaccines for cancer immunotherapy, including DEX combined with cyclophosphamide for NSCLC, TAEs combined with an antisense molecule against glioma, and mesenchymal stromal cell-derived exosomes with KrasG12D siRNA (iExosomes), were studied in pancreatic cancer. A large number of clinical trials have explored the possibility of using exosomes as diagnostic, prognostic and therapeutic markers for lung, prostate, renal cell, gastric, breast, gallbladder, pancreatic, and rectal cancers. The safety and efficacy of exosomes as curcumin carriers have been verified for the treatment of colorectal cancer in clinical trials. Therefore, based on the existing experimental data and clinical trials, exosomes are expected to become biomarkers, drug carriers and immunotherapeutic vaccines for a variety of cancers.

\section{Conclusions}

Although exosomes are a relatively new area of research, there has been widespread interest in the field of cancer therapy regarding the potential use of exosomes as new low-toxicity inhibitors in immunotherapy, as potential cancer markers, or as a safer and more efficient method of delivering anti-cancer drugs. Exosomes, a kind of small extracellular vesicle, can be released by tumor cells or immune cells into the extracellular environment. Increasing studies have led to more recent updates to the evidence suggesting that exosomes can display immunomodulatory properties and operate as potential therapeutic agents. Moreover, exosomes exhibit important functional roles in transferring proteins, nucleic acids, and lipid contents, consequently contributing to intercellular communication and immune regulation [132, 180]. More importantly, some of these biologically active cargoes on exosomes, such as MHC and costimulatory molecules, have been proven to participate in exosome-mediated anti-cancer immune responses. To 
Table 2 The ongoing clinical trials of cancer immunotherapy based on exosomes

\begin{tabular}{|c|c|c|c|c|c|}
\hline ID & Sponsor & Status & Cancer & Therapy strategy & Purpose \\
\hline & & & & & Immunotherapeutic vaccines \\
\hline NCT01159288 & $\begin{array}{l}\text { Gustave Roussy, Cancer } \\
\text { Campus, Grand Paris }\end{array}$ & Completed & NSCLC & $\begin{array}{l}\text { mCTX- and tumor antigen-loaded } \\
\text { Dex }\end{array}$ & $\begin{array}{l}\text { Dex are able to activate innate and } \\
\text { adaptive immunity }\end{array}$ \\
\hline NCT01550523 & $\begin{array}{l}\text { Sidney Kimmel Cancer Center at } \\
\text { Thomas Jefferson University }\end{array}$ & Completed & $\begin{array}{l}\text { Recurrent malignant } \\
\text { gliomas }\end{array}$ & $\begin{array}{l}\text { An antisense molecule designed to } \\
\text { shut down a targeted surface } \\
\text { receptor protein by TAEs }\end{array}$ & $\begin{array}{l}\text { TAEs deliver tumor antigens, and } \\
\text { activate the immune response }\end{array}$ \\
\hline \multirow[t]{2}{*}{ NCT03608631 } & \multirow[t]{2}{*}{ M.D. Anderson Cancer Center } & \multirow[t]{2}{*}{$\begin{array}{l}\text { Not yet } \\
\text { recruiting }\end{array}$} & \multirow[t]{2}{*}{ Pancreas cancer } & \multirow[t]{2}{*}{ iExosomes } & $\begin{array}{l}\text { iExosomes may work better at treating } \\
\text { Metastatic pancreatic cancer with } \\
\text { KrasG12D mutation }\end{array}$ \\
\hline & & & & & $\begin{array}{l}\text { Markers of cancer diagnosis and } \\
\text { prognosis }\end{array}$ \\
\hline NCT03542253 & $\begin{array}{l}\text { Second Affiliated Hospital of } \\
\text { Soochow University }\end{array}$ & $\begin{array}{l}\text { Not yet } \\
\text { recruiting }\end{array}$ & Early lung cancer & None & $\begin{array}{l}\text { Exosomal microRNAs combined } \mathrm{CT} \text { as } \\
\text { early diagnostic markers }\end{array}$ \\
\hline NCT03830619 & Wuhan Union Hospital, China & Recruiting & Lung cancer & None & Exosomal IncRNAs as diagnostic markers \\
\hline NCT03974204 & Centre Oscar Lambret & $\begin{array}{l}\text { Not yet } \\
\text { recruiting }\end{array}$ & $\begin{array}{l}\text { Breast cancer with } \\
\text { leptomeningeal } \\
\text { metastasis }\end{array}$ & None & $\begin{array}{l}\text { Exosomes in the cerebrospinal fluid as } \\
\text { diagnostic markers }\end{array}$ \\
\hline NCT04182893 & Shanghai Chest Hospital & Recruiting & $\begin{array}{l}\text { Malignant pulmonary } \\
\text { nodules }\end{array}$ & None & $\begin{array}{l}\text { ctDNA and exosome RNA combined as } \\
\text { diagnostic markers }\end{array}$ \\
\hline NCT04053855 & $\begin{array}{l}\text { Centre Hospitalier Universitaire } \\
\text { de Saint Etienne }\end{array}$ & Recruiting & $\begin{array}{l}\text { Clear cell renal cell } \\
\text { carcinoma }\end{array}$ & None & $\begin{array}{l}\text { Urinary exosomes as early diagnostic } \\
\text { markers }\end{array}$ \\
\hline NCT03821909 & $\begin{array}{l}\text { The Affiliated Nanjing Drum } \\
\text { Tower Hospital of Nanjing } \\
\text { University Medical School }\end{array}$ & Recruiting & Pancreatic cancer & None & $\begin{array}{l}\text { MicroRNA markers of exosomes from } \\
\text { patients with primary tumors as } \\
\text { diagnostic and prognostic markers }\end{array}$ \\
\hline NCT01344109 & Leo W. Jenkins Cancer Center & Withdrawn & Breast cancer & Neoadjuvant chemotherapy & $\begin{array}{l}\text { TAEs as diagnostic and prognostic } \\
\text { markers }\end{array}$ \\
\hline NCT03911999 & $\begin{array}{l}\text { Chinese University of Hong } \\
\text { Kong }\end{array}$ & Recruiting & Prostate cancer & None & $\begin{array}{l}\text { Exosomal microRNAs as diagnostic and } \\
\text { monitoring markers }\end{array}$ \\
\hline NCT01779583 & Hospital Miguel Servet & Unknown & Gastric cancer & None & $\begin{array}{l}\text { TAEs as diagnostic, prognostic and } \\
\text { predictive markers }\end{array}$ \\
\hline NCT03102268 & $\begin{array}{l}\text { The Second Hospital of Nanjing } \\
\text { Medical University }\end{array}$ & Recruiting & Cholangiocarcinoma & Surgery & $\begin{array}{l}\text { Noncoding RNAs from TAEs as } \\
\text { diagnostic, prognostic and predictive } \\
\text { markers }\end{array}$ \\
\hline NCT02439008 & Centre Oscar Lambret & Terminated & Carcinoma & $\begin{array}{l}\text { High-dose hypofractionated } \\
\text { radiotherapy }\end{array}$ & Early markers of tumor response \\
\hline NCT03874559 & $\begin{array}{l}\text { University of Kansas Medical } \\
\text { Center }\end{array}$ & Recruiting & Rectal cancer & $\begin{array}{l}\text { Neoadjuvant chemoradiation } \\
\text { therapy }\end{array}$ & Pathologic response markers \\
\hline NCT02862470 & $\begin{array}{l}\text { National Taiwan University } \\
\text { Hospital }\end{array}$ & $\begin{array}{l}\text { Active, not } \\
\text { recruiting }\end{array}$ & Thyroid cancer & Lovastatin and Vildagliptin & $\begin{array}{l}\text { Urine exosomes as prognostic markers } \\
\text { and therapeutic targets }\end{array}$ \\
\hline NCT03581435 & $\begin{array}{l}\text { Shanghai Jiao Tong University } \\
\text { School of Medicine }\end{array}$ & Recruiting & $\begin{array}{l}\text { Gallbladder } \\
\text { carcinoma }\end{array}$ & None & $\begin{array}{l}\text { Circulating exosome from blood } \\
\text { specimens as prognostic and predictive } \\
\text { markers }\end{array}$ \\
\hline NCT02310451 & $\begin{array}{l}\text { Centre Hospitalier Universitaire } \\
\text { de Nice }\end{array}$ & Unknown & Metastatic melanoma & $\begin{array}{l}\text { Alkylating agents (temozolomide } \\
\text { and fotemustine) or vemurafenib }\end{array}$ & $\begin{array}{l}\text { Exosomes from senescent Melanoma } \\
\text { cells as a prognostic factor and marker } \\
\text { of therapeutic response }\end{array}$ \\
\hline NCT03985696 & University Hospital, Limoges & Recruiting & $\begin{array}{l}\text { Non-Hodgkin B-cell } \\
\text { lymphomas }\end{array}$ & $\begin{array}{l}\text { Monoclonal anti-CD20 antibody, ri- } \\
\text { tuximab, in combination of CHOP } \\
\text { chemotherapy }\end{array}$ & $\begin{array}{l}\text { Immunotherapeutic targets (CD20, PD- } \\
\text { L1) on exosomes from B-NHL contribute } \\
\text { to therapeutic resistance }\end{array}$ \\
\hline NCT02393703 & $\begin{array}{l}\text { Memorial Sloan Kettering } \\
\text { Cancer Center }\end{array}$ & $\begin{array}{l}\text { Active, not } \\
\text { recruiting }\end{array}$ & Pancreatic cancer & None & $\begin{array}{l}\text { Disease recurrence and outcomes } \\
\text { markers }\end{array}$ \\
\hline NCT03800121 & Centre Georges Francois Leclerc & Recruiting & Sarcoma & None & $\begin{array}{l}\text { Serum TAEs to monitor disease and } \\
\text { predict recurrence }\end{array}$ \\
\hline \multirow[t]{2}{*}{ NCT03108677 } & Ruijin Hospital & Recruiting & $\begin{array}{l}\text { Primary high-grade } \\
\text { osteosarcoma with } \\
\text { lung metastases }\end{array}$ & None & $\begin{array}{l}\text { Circulating exosomal RNA as marker for } \\
\text { lung metastases }\end{array}$ \\
\hline & & & & & Drug delivery carriers \\
\hline NCT01294072 & University of Louisville & $\begin{array}{l}\text { Active, not } \\
\text { recruiting }\end{array}$ & Colon cancer & Curcumin & $\begin{array}{l}\text { Plant exosomes as delivery vehicle for } \\
\text { curcumin }\end{array}$ \\
\hline
\end{tabular}


date, cumulative studies have demonstrated that the exosome-mediated immune response is dependent on the functional link between several immune cells and tumor cells. Thus, a better understanding of the cellspecific molecular events on exosomes would be helpful to pave the way for developing novel potential exosomebased biomarkers and therapeutics. Recent advances in clarifying the molecular and functional profiles of exosomes have also led to the development of increasingly effective agents that might be potentially used in cancer immunotherapies.

Even though exosome-based strategies have been demonstrated to enhance the anti-cancer immunotherapy, the evidence regarding their clinical application in cancer patients has yielded only modest benefits. In particular, there are still some difficulties in the separation, production, biocompatibility and manufacturing practices of exosomes before clinical realization of their full potential [181, 182]. First, most exosomes are currently isolated from cell culture supernatants and complex biological fluids (such as plasma); thus, the production and purity of exosomes are limited [183]. When using exosomes as immunotherapy or for other approaches, largescale stable preparation methods must be achieved. Although some studies have reported protocols for mass production of exosomes and improvements in biocompatibility [184, 185], further preclinical and clinical studies are needed for validation. Furthermore, exosome-based immunotherapy is still in the early clinical trial stage at present, and there are no specific international guidelines for the management of the production and application of this new type of therapeutic agent $[17,186]$. Therefore, before exosomes are officially used in the clinic, the quality classifications and standards for biopharmaceuticals should be addressed, and there is a need to develop specific GMP guidelines as soon as possible to ensure the safety of exosomal treatment.

\section{Abbreviations \\ PD-1: Programmed cell death 1; PD-L1: Programmed cell death 1 ligand 1; TGF- $\beta$ : Transforming growth factor- $\beta$; DC: Dendritic cell; MHC I: Major histocompatibility complex class I molecule; NK: Natural killer; TAE: Tumor- associated exosome; CTL: Cytotoxic T cell; CIK: Cytokine-induced killer cell; MHC II: Major histocompatibility complex class I molecules; IL: Interleukin; TNF: Tumor necrosis factor; IFN: Interferon; APC: Antigen presenting cell; DEX: DC-derived exosome; AFP: a-Fetoprotein; CAR: Chimeric antigen receptor; Tregs: Regulatory T cells; Tfhs: Follicular helper T cells; MDSCs: Myeloid-derived suppressor cells; MCs: Mast cells; LLC: Lewis lung carcinoma; aGC: a-Galactosylceramide; SMART-EXO: Synthetic polyvalent antibody redirected exosome; SMNC-EXO: Exosome-based superparamagnetic nanoparticle cluster}

\section{Acknowledgements}

We thank Elsevier's English Language Editing Service for assistance with language editing.

\section{Authors' contributions}

ZJX, SSZ and YLY wrote this review article. SSZ and ZCG performed technical and administrative support. ZJX and YLY designed the review and contributed to manuscript preparation. All authors reviewed and approved the final version of the manuscript.

\section{Funding}

This work was supported by the National Natural Science Foundation of China (81703036, 81803035); the China Postdoctoral Science Foundation (2020M672521, 2017M610510); the Natural Science Foundation of Hunan Province, China (2020JJ5934, 2019JJ50932); the Postdoctoral Science Foundation of Central South University (248485); and the Youth Science Foundation of Xiangya Hospital (2019Q13).

\section{Availability of data and materials}

Not applicable.

Ethics approval and consent to participate

Not applicable.

Consent for publication

Not applicable.

\section{Competing interests}

The authors declare that they have no competing interests.

\section{Author details}

${ }^{1}$ Department of Pathology, Xiangya Hospital, Central South University, Changsha 410008, Hunan, China. ${ }^{2}$ Department of Pharmacy, Xiangya Hospital, Central South University, 87 Xiangya Road, Changsha 410008, Hunan, China. ${ }^{3}$ National Clinical Research Center for Geriatric Disorders, Xiangya Hospital, Central South University, Changsha 410008, Hunan, China.

Received: 10 June 2020 Accepted: 3 November 2020

Published online: 12 November 2020

\section{References}

1. Bray F, Ferlay J, Soerjomataram I, Siegel RL, Torre LA, Jemal A. Global cancer statistics 2018: GLOBOCAN estimates of incidence and mortality worldwide for 36 cancers in 185 countries. CA Cancer J Clin. 2018;68:394-424.

2. Subedi P, Nembrini S, An Q, Zhu Y, Peng H, Yeh F, Cole SA, Rhoades DA, Lee ET, Zhao J. Telomere length and cancer mortality in American Indians: the Strong Heart Study. Geroscience. 2019;41:351-61.

3. Csiszar A, Balasubramanian P, Tarantini S, Yabluchanskiy A, Zhang XA, Springo Z, Benbrook D, Sonntag WE, Ungvari Z. Chemically induced carcinogenesis in rodent models of aging: assessing organismal resilience to genotoxic stressors in geroscience research. Geroscience. 2019;41:209-27.

4. Yu WD, Sun G, Li J, Xu J, Wang X. Mechanisms and therapeutic potentials of cancer immunotherapy in combination with radiotherapy and/or chemotherapy. Cancer Lett. 2019:452:66-70.

5. Sharma RA, Plummer R, Stock JK, Greenhalgh TA, Ataman O, Kelly S, Clay R, Adams RA, Baird RD, Billingham L, et al. Clinical development of new drugradiotherapy combinations. Nat Rev Clin Oncol. 2016;13:627-42.

6. Wang Z, Tang $Y$, Tan $Y$, Wei Q, Yu W. Cancer-associated fibroblasts in radiotherapy: challenges and new opportunities. Cell Commun Signal. 2019;17:47.

7. Aung TN, Qu Z, Kortschak RD, Adelson DL. Understanding the Effectiveness of Natural Compound Mixtures in Cancer through Their Molecular Mode of Action. Int J Mol Sci. 2017;18.

8. Shi J, Kantoff PW, Wooster R, Farokhzad OC. Cancer nanomedicine: progress, challenges and opportunities. Nat Rev Cancer. 2017;17:20-37.

9. Kennedy LB, Salama AKS. A review of cancer immunotherapy toxicity. CA Cancer J Clin. 2020;70:86-104.

10. Yan Y, Chen X, Wei J, Gong Z, Xu Z. Immunotherapy Combinations in Patients with Small Cell Lung Cancers. J Thorac Oncol. 2019;14:e244-5.

11. Markham A. Tepotinib: First Approval. Drugs. 2020;80:829-33.

12. Barroso-Sousa R, Barry WT, Garrido-Castro AC, Hodi FS, Min L, Krop IE, Tolaney SM. Incidence of Endocrine Dysfunction Following the Use of Different Immune Checkpoint Inhibitor Regimens: A Systematic Review and Meta-analysis. JAMA Oncol. 2018;4:173-82.

13. Xu Z, Wang $X$, Chen X, Zeng S, Gong Z, Yan Y. Pembrolizumab as the firstline monotherapy for non-small-cell lung cancer with a low programmed death ligand 1 threshold. J Cell Commun Signal. 2020;14:129-30. 
14. Meng W, Hao Y, He C, Li L, Zhu G. Exosome-orchestrated hypoxic tumor microenvironment. Mol Cancer. 2019;18:57.

15. Pegtel DM, Gould SJ. Exosomes. Annu Rev Biochem. 2019;88:487-514.

16. Zhang $\mathrm{H}$, Cherian $\mathrm{R}$, Jin K. Systemic milieu and age-related deterioration. Geroscience. 2019;41:275-84.

17. Syn NL, Wang L, Chow EK, Lim CT, Goh BC. Exosomes in Cancer Nanomedicine and Immunotherapy: Prospects and Challenges. Trends Biotechnol. 2017:35:665-76

18. Luke JJ, Flaherty KT, Ribas A, Long GV. Targeted agents and immunotherapies: optimizing outcomes in melanoma. Nat Rev Clin Oncol. 2017;14:463-82.

19. Xu Z, Yan Y, Wang X, Zeng S, Gong Z. Lung Immune Prognostic Index for Outcome Prediction to Immunotherapy in Patients With NSCLC. J Thorac Oncol. 2019;14:e207-8.

20. George S, Rini Bl, Hammers HJ. Emerging Role of Combination Immunotherapy in the First-line Treatment of Advanced Renal Cell Carcinoma: A Review. JAMA Oncol. 2019:5:411-21.

21. Bebelman MP, Smit MJ, Pegtel DM, Baglio SR. Biogenesis and function of extracellular vesicles in cancer. Pharmacol Ther. 2018;188:1-11.

22. Wu F, Li F, Lin X, Xu F, Cui RR, Zhong JY, Zhu T, Shan SK, Liao XB, Yuan LQ, Mo ZH. Exosomes increased angiogenesis in papillary thyroid cancer microenvironment. Endocr Relat Cancer. 2019;26:525-38.

23. Daassi D, Mahoney KM, Freeman GJ. The importance of exosomal PDL1 in tumour immune evasion. Nat Rev Immunol. 2020;20:209-15.

24. Sharma P, Diergaarde B, Ferrone S, Kirkwood JM, Whiteside TL. Melanoma cell-derived exosomes in plasma of melanoma patients suppress functions of immune effector cells. Sci Rep. 2020;10:92.

25. Li XB, Zhang ZR, Schluesener HJ, Xu SQ. Role of exosomes in immune regulation. J Cell Mol Med. 2006;10:364-75.

26. Justiz Vaillant AA, Jan A. Physiology, Immune Response. Treasure Island (FL): StatPearls; 2020.

27. Walker EM, Slisarenko N, Gerrets GL, Kissinger PJ, Didier ES, Kuroda MJ, Veazey RS, Jazwinski SM, Rout N. Inflammaging phenotype in rhesus macaques is associated with a decline in epithelial barrier-protective functions and increased pro-inflammatory function in CD161-expressing cells. Geroscience. 2019;41:739-57.

28. Rozman P. The potential of non-myeloablative heterochronous autologous hematopoietic stem cell transplantation for extending a healthy life span. Geroscience. 2018;40:221-42.

29. Huang Y, Liu K, Li Q, Yao Y, Wang Y. Exosomes Function in Tumor Immune Microenvironment. Adv Exp Med Biol. 2018;1056:109-22.

30. Zech D, Rana S, Buchler MW, Zoller M. Tumor-exosomes and leukocyte activation: an ambivalent crosstalk. Cell Commun Signal. 2012;10:37.

31. Que RS, Lin C, Ding GP, Wu ZR, Cao LP. Increasing the immune activity of exosomes: the effect of miRNA-depleted exosome proteins on activating dendritic cell/cytokine-induced killer cells against pancreatic cancer. J Zhejiang Univ Sci B. 2016;17:352-60.

32. Li W, Mu D, Tian F, Hu Y, Jiang T, Han Y, Chen J, Han G, Li X. Exosomes derived from Rab27aoverexpressing tumor cells elicit efficient induction of antitumor immunity. Mol Med Rep. 2013;8:1876-82.

33. Wang C, Huang X, Wu Y, Wang J, Li F, Guo G. Tumor Cell-associated Exosomes Robustly Elicit Anti-tumor Immune Responses through Modulating Dendritic Cell Vaccines in Lung Tumor. Int J Biol Sci. 2020;16: 633-43.

34. Huang F, Wan J, Hu W, Hao S. Enhancement of Anti-Leukemia Immunity by Leukemia-Derived Exosomes Via Downregulation of TGF-beta1 Expression. Cell Physiol Biochem. 2017:44:240-54.

35. Borst J, Ahrends T, Babala N, Melief CJM, Kastenmuller W. CD4(+) T cell help in cancer immunology and immunotherapy. Nat Rev Immunol. 2018;18: 635-47.

36. Zhang $L$, Romero P. Metabolic Control of CD8(+) T Cell Fate Decisions and Antitumor Immunity. Trends Mol Med. 2018;24:30-48.

37. Zhang Y, Luo CL, He BC, Zhang JM, Cheng G, Wu XH. Exosomes derived from IL-12-anchored renal cancer cells increase induction of specific antitumor response in vitro: a novel vaccine for renal cell carcinoma. Int J Oncol. 2010;36:133-40

38. Zhang J, Zhang Y, Luo C, Xia Y, Chen H, Wu X. Glycosyl-phosphatidylinositolanchored interleukin-2 expressed on tumor-derived exosomes induces antitumor immune response in vitro. Tumori. 2010;96:452-9.

39. Wen SW, Sceneay J, Lima LG, Wong CS, Becker M, Krumeich S, Lobb RJ, Castillo V, Wong KN, Ellis $S$, et al. The Biodistribution and Immune
Suppressive Effects of Breast Cancer-Derived Exosomes. Cancer Res. 2016;76: 6816-27.

40. Maybruck BT, Pfannenstiel LW, Diaz-Montero M, Gastman BR. Tumor-derived exosomes induce CD8(+) T cell suppressors. J Immunother Cancer. 2017;5:65.

41. Bland CL, Byrne-Hoffman CN, Fernandez A, Rellick SL, Deng W, Klinke DJ 2nd. Exosomes derived from B16F0 melanoma cells alter the transcriptome of cytotoxic T cells that impacts mitochondrial respiration. FEBS J. 2018;285: 1033-50.

42. Mirzaei R, Sarkar S, Dzikowski L, Rawji KS, Khan L, Faissner A, Bose P, Yong WW. Brain tumor-initiating cells export tenascin-C associated with exosomes to suppress T cell activity. Oncoimmunology. 2018;7:e1478647.

43. Du YM, Zhuansun YX, Chen R, Lin L, Lin Y, Li JG. Mesenchymal stem cell exosomes promote immunosuppression of regulatory $T$ cells in asthma. Exp Cell Res. 2018;363:114-20.

44. Wen C, Seeger RC, Fabbri M, Wang L, Wayne AS, Jong AY. Biological roles and potential applications of immune cell-derived extracellular vesicles. J Extracell Vesicles. 2017:6:1400370.

45. Dorsam B, Reiners KS, von Strandmann EP. Cancer-derived extracellular vesicles: friend and foe of tumour immunosurveillance. Philos Trans R Soc Lond B Biol Sci. 2018;373.

46. Whiteside TL. Immune modulation of T-cell and NK (natural killer) cell activities by TEXs (tumour-derived exosomes). Biochem Soc Trans. 2013;41: 245-51.

47. Chen W, Jiang J, Xia W, Huang J. Tumor-Related Exosomes Contribute to Tumor-Promoting Microenvironment: An Immunological Perspective. J Immunol Res. 2017;2017:1073947.

48. Lundholm M, Schroder M, Nagaeva O, Baranov V, Widmark A, MinchevaNilsson L, Wikstrom P. Prostate tumor-derived exosomes down-regulate NKG2D expression on natural killer cells and CD8+ T cells: mechanism of immune evasion. PLoS One. 2014;9:e108925.

49. Labani-Motlagh A, Israelsson P, Ottander U, Lundin E, Nagaev I, Nagaeva O, Dehlin E, Baranov V, Mincheva-Nilsson L. Differential expression of ligands for NKG2D and DNAM-1 receptors by epithelial ovarian cancer-derived exosomes and its influence on NK cell cytotoxicity. Tumour Biol. 2016;37:5455-66.

50. Rouce RH, Shaim H, Sekine T, Weber G, Ballard B, Ku S, Barese C, Murali V, Wu MF, Liu H, et al. The TGF-beta/SMAD pathway is an important mechanism for NK cell immune evasion in childhood B-acute lymphoblastic leukemia. Leukemia. 2016;30:800-11.

51. Zhao J, Schlosser HA, Wang Z, Qin J, Li J, Popp F, Popp MC, Alakus H, Chon $\mathrm{SH}$, Hansen HP, et al. Tumor-Derived Extracellular Vesicles Inhibit Natural Killer Cell Function in Pancreatic Cancer. Cancers (Basel). 2019;11.

52. Gastpar R, Gehrmann M, Bausero MA, Asea A, Gross C, Schroeder JA, Multhoff $\mathrm{G}$. Heat shock protein 70 surface-positive tumor exosomes stimulate migratory and cytolytic activity of natural killer cells. Cancer Res. 2005;65:5238-47.

53. Reiners KS, Topolar D, Henke A, Simhadri VR, Kessler J, Sauer M, Bessler M, Hansen HP, Tawadros S, Herling M, et al. Soluble ligands for NK cell receptors promote evasion of chronic lymphocytic leukemia cells from NK cell anti-tumor activity. Blood. 2013;121:3658-65.

54. Vulpis E, Cecere F, Molfetta R, Soriani A, Fionda C, Peruzzi G, Caracciolo G, Palchetti S, Masuelli L, Simonelli L, et al. Genotoxic stress modulates the release of exosomes from multiple myeloma cells capable of activating NK cell cytokine production: Role of HSP70/TLR2/NF-kB axis. Oncoimmunology. 2017;6:e1279372.

55. Lv LH, Wan YL, Lin Y, Zhang W, Yang M, Li GL, Lin HM, Shang CZ, Chen YJ, Min J. Anticancer drugs cause release of exosomes with heat shock proteins from human hepatocellular carcinoma cells that elicit effective natural killer cell antitumor responses in vitro. J Biol Chem. 2012;287:15874-85.

56. Perez CR, De Palma M. Engineering dendritic cell vaccines to improve cancer immunotherapy. Nat Commun. 2019;10:5408.

57. Lindenbergh MFS, Wubbolts R. Borg EGF, van 't Veld EM, Boes M, Stoorvogel W: Dendritic cells release exosomes together with phagocytosed pathogen; potential implications for the role of exosomes in antigen presentation. J Extracell Vesicles. 2020:9:1798606.

58. Chaput N, Taieb J, Schartz NE, Andre F, Angevin E, Zitvogel L. Exosomebased immunotherapy. Cancer Immunol Immunother. 2004:53:234-9.

59. Viaud S, Thery C, Ploix S, Tursz T, Lapierre V, Lantz O, Zitvogel L, Chaput N. Dendritic cell-derived exosomes for cancer immunotherapy: what's next? Cancer Res. 2010;70:1281-5.

60. Hao S, Liu Y, Yuan J, Zhang X, He T, Wu X, Wei Y, Sun D, Xiang J. Novel exosome-targeted $C D 4+T$ cell vaccine counteracting $C D 4+25+$ regulatory $T$ 
cell-mediated immune suppression and stimulating efficient central memory CD8+ CTL responses. J Immunol. 2007:179:2731-40.

61. Wang L, Xie Y, Ahmed KA, Ahmed S, Sami A, Chibbar R, Xu Q, Kane SE, Hao $\mathrm{S}$, Mulligan SJ, Xiang J. Exosomal pMHC-I complex targets T cell-based vaccine to directly stimulate $C T L$ responses leading to antitumor immunity in transgenic FVBneuN and HLA-A2/HER2 mice and eradicating trastuzumab-resistant tumor in athymic nude mice. Breast Cancer Res Treat. 2013;140:273-84.

62. Amigorena S. Cancer immunotherapy using dendritic cell-derived exosomes. Medicina (B Aires). 2000;60(Suppl 2):51-4.

63. Lu Z, Zuo B, Jing R, Gao X, Rao Q, Liu Z, Qi H, Guo H, Yin H. Dendritic cellderived exosomes elicit tumor regression in autochthonous hepatocellular carcinoma mouse models. J Hepatol. 2017;67:739-48.

64. Taieb J, Chaput N, Schartz N, Roux S, Novault S, Menard C, Ghiringhelli F, Terme M, Carpentier AF, Darrasse-Jeze G, et al. Chemoimmunotherapy of tumors: cyclophosphamide synergizes with exosome based vaccines. J Immunol. 2006;176:2722-9.

65. Hiltbrunner S, Larssen P, Eldh M, Martinez-Bravo MJ, Wagner AK, Karlsson MC, Gabrielsson S. Exosomal cancer immunotherapy is independent of MHC molecules on exosomes. Oncotarget. 2016;7:38707-17.

66. Chen Z, You L, Wang L, Huang X, Liu H, Wei JY, Zhu L, Qian W. Dual effect of DLBCL-derived EXOs in lymphoma to improve DC vaccine efficacy in vitro while favor tumorgenesis in vivo. J Exp Clin Cancer Res. 2018;37:190.

67. Klinker MW, Lizzio V, Reed TJ, Fox DA, Lundy SK. Human B Cell-Derived Lymphoblastoid Cell Lines Constitutively Produce Fas Ligand and Secrete MHCII(+)FasL(+) Killer Exosomes. Front Immunol. 2014;5:144.

68. Chen W, Wang J, Shao C, Liu S, Yu Y, Wang Q, Cao X. Efficient induction of antitumor $\mathrm{T}$ cell immunity by exosomes derived from heat-shocked lymphoma cells. Eur J Immunol. 2006;36:1598-607.

69. Neelapu SS, Tummala S, Kebriaei P, Wierda W, Gutierrez C, Locke FL, Komanduri KV, Lin Y, Jain N, Daver N, et al. Chimeric antigen receptor T-cell therapy - assessment and management of toxicities. Nat Rev Clin Oncol. 2018;15:47-62.

70. Fu W, Lei C, Liu S, Cui Y, Wang C, Qian K, Li T, Shen Y, Fan X, Lin F, et al. CAR exosomes derived from effector CAR-T cells have potent antitumour effects and low toxicity. Nat Commun. 2019:10:4355.

71. Geltink RIK, Kyle RL, Pearce EL. Unraveling the Complex Interplay Between T Cell Metabolism and Function. Annu Rev Immunol. 2018;36:461-88.

72. Lu J, Wu J, Tian J, Wang S. Role of T cell-derived exosomes in immunoregulation. Immunol Res. 2018;66:313-22.

73. Tang $X J$, Sun $X Y$, Huang KM, Zhang L, Yang ZS, Zou DD, Wang B, Warnock GL, Dai LJ, Luo J. Therapeutic potential of CAR-T cell-derived exosomes: a cell-free modality for targeted cancer therapy. Oncotarget. 2015:6:44179-90.

74. Seo N, Shirakura Y, Tahara Y, Momose F, Harada N, Ikeda H, Akiyoshi K, Shiku H. Activated CD8(+) T cell extracellular vesicles prevent tumour progression by targeting of lesional mesenchymal cells. Nat Commun. 2018;9:435.

75. Wu SW, Li L, Wang Y, Xiao Z. CTL-Derived Exosomes Enhance the Activation of CTLs Stimulated by Low-Affinity Peptides. Front Immunol. 2019;10:1274.

76. Li L, Jay SM, Wang Y, Wu SW, Xiao Z. IL-12 stimulates CTLs to secrete exosomes capable of activating bystander CD8(+) T cells. Sci Rep. 2017;7:13365.

77. Mittelbrunn M, Gutierrez-Vazquez C, Villarroya-Beltri C, Gonzalez S, SanchezCabo F, Gonzalez MA, Bernad A, Sanchez-Madrid F. Unidirectional transfer of microRNA-loaded exosomes from T cells to antigen-presenting cells. Nat Commun. 2011:2:282.

78. Tumne A, Prasad VS, Chen Y, Stolz DB, Saha K, Ratner DM, Ding M, Watkins SC, Gupta P. Noncytotoxic suppression of human immunodeficiency virus type 1 transcription by exosomes secreted from CD8+ T cells. J Virol. 2009; 83:4354-64.

79. Cai Z, Yang F, Yu L, Yu Z, Jiang L, Wang Q, Yang Y, Wang L, Cao X, Wang J. Activated T cell exosomes promote tumor invasion via Fas signaling pathway. J Immunol. 2012;188:5954-61.

80. Xie Y, Zhang H, Li W, Deng Y, Munegowda MA, Chibbar R, Qureshi M, Xiang J. Dendritic cells recruit T cell exosomes via exosomal LFA-1 leading to inhibition of CD8+ CTL responses through downregulation of peptide/MHC class I and Fas ligand-mediated cytotoxicity. J Immunol. 2010;185:5268-78.

81. Wang X, Shen H, He Q, Tian W, Xia A, Lu XJ. Exosomes derived from exhausted CD8+ T cells impaired the anticancer function of normal CD8+ T cells. J Med Genet. 2019:56:29-31.
82. Zhang H, Xie Y, Li W, Chibbar R, Xiong S, Xiang J. CD4(+) T cell-released exosomes inhibit CD8(+) cytotoxic T-lymphocyte responses and antitumor immunity. Cell Mol Immunol. 2011;8:23-30.

83. Azimi M, Ghabaee $M$, Naser Moghadasi A, Izad M. Altered Expression of miR-326 in T Cell-derived Exosomes of Patients with Relapsing-remitting Multiple Sclerosis. Iran J Allergy Asthma Immunol. 2019;18:108-13.

84. de Carvalho JV, de Castro RO, da Silva EZ, Silveira PP, da Silva-Januario ME, Arruda E, Jamur MC, Oliver C. Aguiar RS, daSilva LL: Nef neutralizes the ability of exosomes from CD4+ T cells to act as decoys during HIV-1 infection. PLoS One. 2014;9:e113691.

85. Zakharova L, Svetlova M, Fomina AF. T cell exosomes induce cholesterol accumulation in human monocytes via phosphatidylserine receptor. J Cell Physiol. 2007;212:174-81.

86. Yang J, Bi L, He X, Wang Z, Qian Y, Xiao L, Shi B. Follicular Helper T Cell Derived Exosomes Promote B Cell Proliferation and Differentiation in Antibody-Mediated Rejection after Renal Transplantation. Biomed Res Int. 2019:2019:6387924.

87. Okoye IS, Coomes SM, Pelly VS, Czieso S, Papayannopoulos V, Tolmachova T, Seabra MC, Wilson MS. MicroRNA-containing T-regulatory-cell-derived exosomes suppress pathogenic T helper 1 cells. Immunity. 2014;41:89-103.

88. Aiello S, Rocchetta F, Longaretti L, Faravelli S, Todeschini M, Cassis L, Pezzuto F, Tomasoni S, Azzollini N, Mister M, et al. Extracellular vesicles derived from $T$ regulatory cells suppress $T$ cell proliferation and prolong allograft survival. Sci Rep. 2017;7:11518.

89. Azimi M, Ghabaee M, Moghadasi AN, Noorbakhsh F, Izad M. Immunomodulatory function of Treg-derived exosomes is impaired in patients with relapsing-remitting multiple sclerosis. Immunol Res. 2018;66: $513-20$.

90. Xie Y, Zhang X, Zhao T, Li W, Xiang J. Natural CD8(+)25(+) regulatory T cellsecreted exosomes capable of suppressing cytotoxic T lymphocytemediated immunity against B16 melanoma. Biochem Biophys Res Commun. 2013:438:152-5.

91. Yu X, Huang C, Song B, Xiao Y, Fang M, Feng J, Wang P. CD4+CD25+ regulatory $T$ cells-derived exosomes prolonged kidney allograft survival in a rat model. Cell Immunol. 2013;285:62-8.

92. Smyth LA, Ratnasothy K, Tsang JY, Boardman D, Warley A, Lechler R, Lombardi G. CD73 expression on extracellular vesicles derived from CD4+ CD25+ Foxp3+ T cells contributes to their regulatory function. Eur J Immunol. 2013:43:2430-40.

93. Chen L, Huang H, Zhang W, Ding F, Fan Z, Zeng Z. Exosomes Derived From T Regulatory Cells Suppress CD8+ Cytotoxic T Lymphocyte Proliferation and Prolong Liver Allograft Survival. Med Sci Monit. 2019;25:4877-84.

94. Wu J, Gao FX, Wang C, Qin M, Han F, Xu T, Hu Z, Long Y, He XM, Deng X, et al. IL-6 and IL-8 secreted by tumour cells impair the function of NK cells via the STAT3 pathway in oesophageal squamous cell carcinoma. J Exp Clin Cancer Res. 2019;38:321.

95. Lugini L, Cecchetti S, Huber V, Luciani F, Macchia G, Spadaro F, Paris L, Abalsamo L, Colone M, Molinari A, et al. Immune surveillance properties of human NK cell-derived exosomes. J Immunol. 2012;189:2833-42.

96. Fais S. NK cell-released exosomes: Natural nanobullets against tumors. Oncoimmunology. 2013;2:e22337.

97. Di Pace AL, Tumino N, Besi F, Alicata C, Conti LA, Munari E, Maggi E, Vacca P. Moretta L. Characterization of Human NK Cell-Derived Exosomes: Role of DNAM1 Receptor In Exosome-Mediated Cytotoxicity Against Tumor. Cancers (Basel). 2020;12.

98. Federici C, Shahaj E, Cecchetti S, Camerini S, Casella M, lessi E, Camisaschi C, Paolino G, Calvieri S, Ferro S, et al. Natural-Killer-Derived Extracellular Vesicles: Immune Sensors and Interactors. Front Immunol. 2020;11:262.

99. Zhu L, Kalimuthu S, Gangadaran P, Oh JM, Lee HW, Baek SH, Jeong SY, Lee SW, Lee J, Ahn BC. Exosomes Derived From Natural Killer Cells Exert Therapeutic Effect in Melanoma. Theranostics. 2017;7:2732-45.

100. Wu CH, Li J, Li L, Sun J, Fabbri M, Wayne AS, Seeger RC, Jong AY. Extracellular vesicles derived from natural killer cells use multiple cytotoxic proteins and killing mechanisms to target cancer cells. J Extracell Vesicles. 2019;8:1588538.

101. Neviani P, Wise PM, Murtadha M, Liu CW, Wu CH, Jong AY, Seeger RC, Fabbri M. Natural Killer-Derived Exosomal miR-186 Inhibits Neuroblastoma Growth and Immune Escape Mechanisms. Cancer Res. 2019;79:1151-64.

102. Zhu L, Kalimuthu S, Oh JM, Gangadaran P, Baek SH, Jeong SY, Lee SW, Lee J. Ahn BC. Enhancement of antitumor potency of extracellular vesicles 
derived from natural killer cells by IL-15 priming. Biomaterials. 2019;190-191: 38-50.

103. Guillerey C, Huntington ND, Smyth MJ. Targeting natural killer cells in cancer immunotherapy. Nat Immunol. 2016;17:1025-36.

104. Jong AY, Wu CH, Li J, Sun J, Fabbri M, Wayne AS, Seeger RC. Large-scale isolation and cytotoxicity of extracellular vesicles derived from activated human natural killer cells. J Extracell Vesicles. 2017;6:1294368.

105. Fu Y, Liu S, Zeng S, Shen H. From bench to bed: the tumor immune microenvironment and current immunotherapeutic strategies for hepatocellular carcinoma. J Exp Clin Cancer Res. 2019;38:396.

106. Yang L, Li A, Lei Q, Zhang Y. Tumor-intrinsic signaling pathways: key roles in the regulation of the immunosuppressive tumor microenvironment. J Hematol Oncol. 2019;12:125.

107. Wang Z, Till B, Gao Q. Chemotherapeutic agent-mediated elimination of myeloid-derived suppressor cells. Oncoimmunology. 2017;6:e1331807.

108. Burke M, Choksawangkarn W, Edwards N, Ostrand-Rosenberg S, Fenselau C. Exosomes from myeloid-derived suppressor cells carry biologically active proteins. J Proteome Res. 2014;13:836-43.

109. Zhu D, Tian J, Wu X, Li M, Tang X, Rui K, Guo H, Ma J, Xu H, Wang S. GMDSC-derived exosomes attenuate collagen-induced arthritis by impairing Th1 and Th17 cell responses. Biochim Biophys Acta Mol Basis Dis. 2019; 1865:165540.

110. Zoller M, Zhao K, Kutlu N, Bauer N, Provaznik J, Hackert T, Schnolzer M. Immunoregulatory Effects of Myeloid-Derived Suppressor Cell Exosomes in Mouse Model of Autoimmune Alopecia Areata. Front Immunol. 2018;9:1279.

111. Geis-Asteggiante L, Belew AT, Clements VK, Edwards NJ, Ostrand-Rosenberg S, El-Sayed NM, Fenselau C. Differential Content of Proteins, mRNAs, and miRNAs Suggests that MDSC and Their Exosomes May Mediate Distinct Immune Suppressive Functions. J Proteome Res. 2018;17:486-98.

112. Deng Z, Rong Y, Teng Y, Zhuang X, Samykutty A, Mu J, Zhang L, Cao P, Yan J, Miller D, Zhang HG. Exosomes miR-126a released from MDSC induced by DOX treatment promotes lung metastasis. Oncogene. 2017; 36:639-51.

113. Zoller M. Janus-Faced Myeloid-Derived Suppressor Cell Exosomes for the Good and the Bad in Cancer and Autoimmune Disease. Front Immunol. 2018;9:137.

114. Arteaga-Blanco LA, Mojoli A, Monteiro RQ, Sandim V, Menna-Barreto RFS, Pereira-Dutra FS, Bozza PT, Resende RO, Bou-Habib DC. Characterization and internalization of small extracellular vesicles released by human primary macrophages derived from circulating monocytes. PLoS One. 2020;15:e0237795.

115. Cheng L, Wang Y, Huang L. Exosomes from M1-Polarized Macrophages Potentiate the Cancer Vaccine by Creating a Pro-inflammatory Microenvironment in the Lymph Node. Mol Ther. 2017;25:1665-75.

116. Singhto N, Kanlaya R, Nilnumkhum A, Thongboonkerd V. Roles of Macrophage Exosomes in Immune Response to Calcium Oxalate Monohydrate Crystals. Front Immunol. 2018;9:316.

117. O'Neill HC, Quah BJ. Exosomes secreted by bacterially infected macrophages are proinflammatory. Sci Signal. 2008;1:pe8.

118. Zhou J, Li X, Wu X, Zhang T, Zhu Q, Wang X, Wang H, Wang K, Lin Y, Wang $X$. Exosomes Released from Tumor-Associated Macrophages Transfer miRNAs That Induce a Treg/Th17 Cell Imbalance in Epithelial Ovarian Cancer. Cancer Immunol Res. 2018;6:1578-92.

119. Yin Z, Ma T, Huang B, Lin L, Zhou Y, Yan J, Zou Y, Chen S. Macrophagederived exosomal microRNA-501-3p promotes progression of pancreatic ductal adenocarcinoma through the TGFBR3-mediated TGF-beta signaling pathway. J Exp Clin Cancer Res. 2019;38:310.

120. Zheng P, Chen L, Yuan X, Luo Q, Liu Y, Xie G, Ma Y, Shen L. Exosomal transfer of tumor-associated macrophage-derived miR-21 confers cisplatin resistance in gastric cancer cells. J Exp Clin Cancer Res. 2017;36:53.

121. Zheng P, Luo Q, Wang W, Li J, Wang T, Wang P, Chen L, Zhang P, Chen H, Liu $Y$, et al. Tumor-associated macrophages-derived exosomes promote the migration of gastric cancer cells by transfer of functional Apolipoprotein $E$. Cell Death Dis. 2018;9:434.

122. Lan J, Sun L, Xu F, Liu L, Hu F, Song D, Hou Z, Wu W, Luo X, Wang J, et al. M2 Macrophage-Derived Exosomes Promote Cell Migration and Invasion in Colon Cancer. Cancer Res. 2019;79:146-58.

123. Binenbaum Y, Fridman E, Yaari Z, Milman N, Schroeder A, Ben David G, Shlomi T, Gil Z. Transfer of miRNA in Macrophage-Derived Exosomes Induces Drug Resistance in Pancreatic Adenocarcinoma. Cancer Res. 2018; 78:5287-99.
124. Cianciaruso C, Beltraminelli T, Duval F, Nassiri S, Hamelin R, Mozes A, GallartAyala H, Ceada Torres G, Torchia B, Ries CH, et al. Molecular Profiling and Functional Analysis of Macrophage-Derived Tumor Extracellular Vesicles. Cell Rep. 2019;27:3062-80 e3011.

125. Choo YW, Kang M, Kim HY, Han J, Kang S, Lee JR, Jeong GJ, Kwon SP, Song SY, Go S, et al. M1 Macrophage-Derived Nanovesicles Potentiate the Anticancer Efficacy of Immune Checkpoint Inhibitors. ACS Nano. 2018;12:8977-93.

126. Xu Y, Liu Y, Yang C, Kang L, Wang M, Hu J, He H, Song W, Tang H. Macrophages transfer antigens to dendritic cells by releasing exosomes containing dead-cell-associated antigens partially through a ceramidedependent pathway to enhance CD4(+) T-cell responses. Immunology. 2016;149:157-71.

127. Sun B, Peng J, Wang S, Liu X, Zhang K, Zhang Z, Wang C, Jing X, Zhou C, Wang $Y$. Applications of stem cell-derived exosomes in tissue engineering and neurological diseases. Rev Neurosci. 2018;29:531-46.

128. Ekstrom K, Valadi H, Sjostrand M, Malmhall C, Bossios A, Eldh M, Lotvall J. Characterization of mRNA and microRNA in human mast cell-derived exosomes and their transfer to other mast cells and blood CD34 progenitor cells. J Extracell Vesicles. 2012;1.

129. Li M, Zhao J, Cao M, Liu R, Chen G, Li S, Xie Y, Xie J, Cheng Y, Huang L, et al. Mast cells-derived MiR-223 destroys intestinal barrier function by inhibition of CLDN8 expression in intestinal epithelial cells. Biol Res. 2020;53:12.

130. Xiao H, Lasser C, Shelke GV, Wang J, Radinger M, Lunavat TR, Malmhall C, Lin LH, Li J, Li L, Lotvall J. Mast cell exosomes promote lung adenocarcinoma cell proliferation - role of KIT-stem cell factor signaling. Cell Commun Signal. 2014;12:64.

131. Yin Y, Shelke GV, Lasser C, Brismar H, Lotvall J. Extracellular vesicles from mast cells induce mesenchymal transition in airway epithelial cells. Respir Res. 2020;21:101.

132. Li F, Wang Y, Lin L, Wang J, Xiao H, Li J, Peng X, Dai H, Li L. Mast CellDerived Exosomes Promote Th2 Cell Differentiation via OX40L-OX40 Ligation. J Immunol Res. 2016;2016:3623898.

133. Skokos D, Botros HG, Demeure C, Morin J, Peronet R, Birkenmeier G, Boudaly S, Mecheri S. Mast cell-derived exosomes induce phenotypic and functional maturation of dendritic cells and elicit specific immune responses in vivo. J Immunol. 2003;170:3037-45.

134. Vargas A, Roux-Dalvai F, Droit A, Lavoie JP. Neutrophil-Derived Exosomes: A New Mechanism Contributing to Airway Smooth Muscle Remodeling. Am J Respir Cell Mol Biol. 2016;55:450-61.

135. Shao S, Fang H, Zhang J, Jiang M, Xue K, Ma J, Zhang J, Lei J, Zhang Y, Li B, et al. Neutrophil exosomes enhance the skin autoinflammation in generalized pustular psoriasis via activating keratinocytes. FASEB J. 2019;33: 6813-28.

136. Brook AC, Jenkins RH, Clayton A, Kift-Morgan A, Raby AC, Shephard AP, Mariotti B, Cuff SM, Bazzoni F, Bowen T, et al. Neutrophil-derived miR-223 as local biomarker of bacterial peritonitis. Sci Rep. 2019;9:10136.

137. Allen ER, Lempke SL, Miller MM, Bush DM, Braswell BG, Estes CL, Benedict EL, Mahon AR, Sabo SL, Greenlee-Wacker MC. Effect of extracellular vesicles from S. aureus-challenged human neutrophils on macrophages. J Leukoc Biol. 2020.

138. Genschmer KR, Russell DW, Lal C, Szul T, Bratcher PE, Noerager BD, Abdul Roda M, Xu X, Rezonzew G, Viera L, et al. Activated PMN Exosomes: Pathogenic Entities Causing Matrix Destruction and Disease in the Lung. Cell. 2019;176:113-26 e115.

139. Li L, Zuo X, Xiao Y, Liu D, Luo H, Zhu H. Neutrophil-derived exosome from systemic sclerosis inhibits the proliferation and migration of endothelial cells. Biochem Biophys Res Commun. 2020;526:334-40.

140. Yoshimura A, Sawada K, Kimura T. Is the exosome a potential target for cancer immunotherapy? Ann Transl Med. 2017:5:117.

141. Li LM, Liu ZX, Cheng QY. Exosome plays an important role in the development of hepatocellular carcinoma. Pathol Res Pract. 2019;215: 152468.

142. Zhu M, Li Y, Shi J, Feng W, Nie G, Zhao Y. Exosomes as extrapulmonary signaling conveyors for nanoparticle-induced systemic immune activation. Small. 2012;8:404-12.

143. Gu X, Erb U, Buchler MW, Zoller M. Improved vaccine efficacy of tumor exosome compared to tumor lysate loaded dendritic cells in mice. Int J Cancer. 2015;136:E74-84.

144. Altieri SL, Khan AN, Tomasi TB. Exosomes from plasmacytoma cells as a tumor vaccine. J Immunother. 2004;27:282-8. 
145. Lee YS, Kim SH, Cho JA, Kim CW. Introduction of the CIITA gene into tumor cells produces exosomes with enhanced anti-tumor effects. Exp Mol Med. 2011;43:281-90.

146. Mahaweni NM, Kaijen-Lambers ME, Dekkers J, Aerts JG, Hegmans JP. Tumour-derived exosomes as antigen delivery carriers in dendritic cellbased immunotherapy for malignant mesothelioma. J Extracell Vesicles. 2013;2.

147. Whiteside TL. Tumor-Derived Exosomes and Their Role in Cancer Progression. Adv Clin Chem. 2016;74:103-41.

148. Tian X, Zhu M, Nie G. How can nanotechnology help membrane vesiclebased cancer immunotherapy development? Hum Vaccin Immunother. 2013:9:222-5.

149. Gehrmann U, Hiltbrunner S, Naslund TI, Gabrielsson S. Potentiating antitumor immunity with alphaGC-loaded exosomes. Oncoimmunology. 2013;2:e26261

150. Theodoraki MN, Yerneni S, Gooding WE, Ohr J, Clump DA, Bauman JE, Ferris RL, Whiteside TL. Circulating exosomes measure responses to therapy in head and neck cancer patients treated with cetuximab, ipilimumab, and IMRT. Oncoimmunology. 2019;8:1593805.

151. Sundararajan V, Sarkar FH, Ramasamy TS. The multifaceted role of exosomes in cancer progression: diagnostic and therapeutic implications [corrected]. Cell Oncol (Dordr). 2018;41:223-52.

152. Anel A, Gallego-Lleyda A, de Miguel D, Naval J, Martinez-Lostao L. Role of Exosomes in the Regulation of T-cell Mediated Immune Responses and in Autoimmune Disease. Cells. 2019;8.

153. de Candia P, Torri A, Pagani M, Abrignani S. Serum microRNAs as Biomarkers of Human Lymphocyte Activation in Health and Disease. Front Immunol. 2014;5:43.

154. Peng XX, Yu RY, Wu X, Wu SY, Pi C, Chen ZH, Zhang XC, Gao CY, Shao YW, Liu $L$, et al. Correlation of plasma exosomal microRNAs with the efficacy of immunotherapy in EGFR / ALK wild-type advanced non-small cell lung cancer. J Immunother Cancer. 2020;8.

155. Anticoli S, Manfredi F, Chiozzini C, Arenaccio C, Olivetta E, Ferrantelli F, Capocefalo A, Falcone E, Ruggieri A, Federico M. An Exosome-Based Vaccine Platform Imparts Cytotoxic T Lymphocyte Immunity Against Viral Antigens. Biotechnol J. 2018;13:e1700443.

156. Naseri M, Bozorgmehr M, Zoller M, Ranaei Pirmardan E, Madjd Z. Tumorderived exosomes: the next generation of promising cell-free vaccines in cancer immunotherapy. Oncoimmunology. 2020;9:1779991.

157. Hsu DH, Paz P, Villaflor G, Rivas A, Mehta-Damani A, Angevin E, Zitvogel L, Le Pecq JB. Exosomes as a tumor vaccine: enhancing potency through direct loading of antigenic peptides. J Immunother. 2003;26:440-50

158. Xiao L, Erb U, Zhao K, Hackert T, Zoller M. Efficacy of vaccination with tumor-exosome loaded dendritic cells combined with cytotoxic drug treatment in pancreatic cancer. Oncoimmunology. 2017;6:e1319044.

159. Xie Y, Wang L, Freywald A, Qureshi M, Chen Y, Xiang J. A novel T cell-based vaccine capable of stimulating long-term functional $C T L$ memory against B16 melanoma via CD40L signaling. Cell Mol Immunol. 2013;10:72-7.

160. Li R, Chibbar R, Xiang J. Novel EXO-T vaccine using polyclonal CD4(+) T cells armed with HER2-specific exosomes for HER2-positive breast cancer. Onco Targets Ther. 2018;11:7089-93.

161. Samuel M, Gabrielsson S. Personalized medicine and back-allogeneic exosomes for cancer immunotherapy. J Intern Med. 2019.

162. Gehrmann U, Naslund TI, Hiltbrunner S, Larssen P, Gabrielsson S. Harnessing the exosome-induced immune response for cancer immunotherapy. Semin Cancer Biol. 2014;28:58-67.

163. Shi X, Cheng Q, Hou T, Han M, Smbatyan G, Lang JE, Epstein AL, Lenz HJ, Zhang Y. Genetically Engineered Cell-Derived Nanoparticles for Targeted Breast Cancer Immunotherapy. Mol Ther. 2020;28:536-47.

164. Cheng Q, Shi X, Zhang Y. Reprogramming Exosomes for Immunotherapy. Methods Mol Biol. 2020;2097:197-209.

165. Ruiss R, Jochum S, Mocikat R, Hammerschmidt W, Zeidler R. EBV-gp350 confers B-cell tropism to tailored exosomes and is a neo-antigen in normal and malignant B cells--a new option for the treatment of B-CLL. PLoS One. 2011;6:e25294

166. Xie F, Zhou X, Fang M, Li H, Su P, Tu Y, Zhang L, Zhou F. Extracellular Vesicles in Cancer Immune Microenvironment and Cancer Immunotherapy. Adv Sci (Weinh). 2019;6:1901779.
167. Rayamajhi S, Nguyen TDT, Marasini R, Aryal S. Macrophage-derived exosome-mimetic hybrid vesicles for tumor targeted drug delivery. Acta Biomater. 2019;94:482-94.

168. Kim MS, Haney MJ, Zhao Y, Yuan D, Deygen I, Klyachko NL, Kabanov AV, Batrakova EV. Engineering macrophage-derived exosomes for targeted paclitaxel delivery to pulmonary metastases: in vitro and in vivo evaluations. Nanomedicine. 2018;14:195-204.

169. Wang G, Hu W, Chen H, Shou X, Ye T, Xu Y. Cocktail Strategy Based on NK Cell-Derived Exosomes and Their Biomimetic Nanoparticles for Dual Tumor Therapy. Cancers (Basel). 2019;11.

170. Qi H, Liu C, Long L, Ren Y, Zhang S, Chang X, Qian X, Jia H, Zhao J, Sun J, et al. Blood Exosomes Endowed with Magnetic and Targeting Properties for Cancer Therapy. ACS Nano. 2016;10:3323-33.

171. Roucourt B, Meeussen S, Bao J, Zimmermann P, David G. Heparanase activates the syndecan-syntenin-ALIX exosome pathway. Cell Res. 2015;25: 412-28.

172. Syn N, Wang L, Sethi G, Thiery JP, Goh BC. Exosome-Mediated Metastasis: From Epithelial-Mesenchymal Transition to Escape from Immunosurveillance. Trends Pharmacol Sci. 2016;37:606-17.

173. Galbo PM Jr, Ciesielski MJ, Figel S, Maguire O, Qiu J, Wiltsie L, Minderman H, Fenstermaker RA. Circulating CD9+/GFAP+/survivin+ exosomes in malignant glioma patients following survivin vaccination. Oncotarget. 2017; 8:114722-35.

174. Sharma A, Johnson A. Exosome DNA: Critical regulator of tumor immunity and a diagnostic biomarker. J Cell Physiol. 2020;235:1921-32.

175. Escudier B, Dorval T, Chaput N, Andre F, Caby MP, Novault S, Flament C, Leboulaire C, Borg C, Amigorena S, et al. Vaccination of metastatic melanoma patients with autologous dendritic cell (DC) derived-exosomes: results of thefirst phase I clinical trial. J Transl Med. 2005;3:10.

176. Morse MA, Garst J, Osada T, Khan S, Hobeika A, Clay TM, Valente N, Shreeniwas R, Sutton MA, Delcayre A, et al. A phase I study of dexosome immunotherapy in patients with advanced non-small cell lung cancer. J Transl Med. 2005:3:9.

177. Zhou J, Li XL, Chen ZR, Chng WJ. Tumor-derived exosomes in colorectal cancer progression and their clinical applications. Oncotarget. 2017;8: 100781-90.

178. Katakowski M, Chopp M. Exosomes as Tools to Suppress Primary Brain Tumor. Cell Mol Neurobiol. 2016;36:343-52.

179. Bell BM, Kirk ID, Hiltbrunner S, Gabrielsson S, Bultema JJ. Designer exosomes as next-generation cancer immunotherapy. Nanomedicine. 2016;12:163-9.

180. Azoulay-Alfaguter I, Mor A. Proteomic analysis of human T cell-derived exosomes reveals differential RAS/MAPK signaling. Eur J Immunol. 2018;48: 1915-7.

181. Lobb RJ, Becker M, Wen SW, Wong CS, Wiegmans AP, Leimgruber A, Moller A. Optimized exosome isolation protocol for cell culture supernatant and human plasma. J Extracell Vesicles. 2015;4:27031.

182. Li C, Donninger H, Eaton J, Yaddanapudi K. Regulatory Role of Immune CellDerived Extracellular Vesicles in Cancer: The Message Is in the Envelope. Front Immunol. 2020;11:1525.

183. Emam SE, Ando H, Abu Lila AS, Shimizu T, Ukawa M, Okuhira K, Ishima Y, Mahdy MA, Ghazy FS, Ishida T. A Novel Strategy to Increase the Yield of Exosomes (Extracellular Vesicles) for an Expansion of Basic Research. Biol Pharm Bull. 2018;41:733-42.

184. Patel GK, Khan MA, Zubair H, Srivastava SK, Khushman M, Singh S, Singh AP. Comparative analysis of exosome isolation methods using culture supernatant for optimum yield, purity and downstream applications. Sci Rep. 2019;9:5335.

185. He L, Zhu D, Wang J, Wu X. A highly efficient method for isolating urinary exosomes. Int J Mol Med. 2019:43:83-90.

186. Zhang L, Yu D. Exosomes in cancer development, metastasis, and immunity. Biochim Biophys Acta Rev Cancer. 1871;2019:455-68.

\section{Publisher's Note}

Springer Nature remains neutral with regard to jurisdictional claims in published maps and institutional affiliations. 